\title{
Petrogenesis of the Loch Bà ring-dyke and Centre 3 granites, Isle of Mull, Scotland
}

\author{
Valentin R. Troll ${ }^{1} \odot \cdot$ Graeme R. Nicoll $^{2} \cdot$ Robert M. Ellam ${ }^{3} \cdot$ C. Henry Emeleus ${ }^{4} \cdot$ Tobias Mattsson $^{5}$
}

Received: 3 August 2020 / Accepted: 5 December 2020 / Published online: 9 February 2021

(c) The Author(s) 2021

\begin{abstract}
The Loch Bà ring-dyke and the associated Centre 3 granites represent the main events of the final phase of activity at the Palaeogene Mull igneous complex. The Loch Bà ring-dyke is one of the best exposed ring-intrusions in the world and records intense interaction between rhyolitic and basaltic magma. To reconstruct the evolutionary history of the Centre 3 magmas, we present new major- and trace-element, and new $\mathrm{Sr}$ isotope data as well as the first $\mathrm{Nd}$ and $\mathrm{Pb}$ isotope data for the felsic and mafic components of the Loch Bà intrusion and associated Centre 3 granites. We also report new $\mathrm{Sr}, \mathrm{Nd}$ and $\mathrm{Pb}$ isotope data for the various crustal compositions from the region, including Moine and Dalradian metasedimentary rocks, Lewisian gneiss, and Iona Group metasediments. Isotope data for the Loch Bà rhyolite $\left({ }^{87} \mathrm{Sr}^{86} \mathrm{Sr}_{\mathrm{i}}=0.716\right)$ imply a considerable contribution of local Moine-type metasedimentary crust $\left({ }^{87} \mathrm{Sr} /{ }^{86} \mathrm{Sr}=0.717-0.736\right)$, whereas Loch Bà mafic inclusions $\left({ }^{87} \mathrm{Sr} /{ }^{86} \mathrm{Sr}_{\mathrm{i}}=0.704-0.707\right)$ are closer to established mantle values, implying that felsic melts of dominantly crustal origin mixed with newly arriving basalt. The Centre 3 microgranites $\left({ }^{87} \mathrm{Sr}^{86} \mathrm{Sr}_{\mathrm{i}}=0.709-0.716\right)$, are less intensely affected by crustal assimilation relative to the Loch Bá rhyolite. Pb-isotope data confirm incorporation of Moine metasediments within the Centre 3 granites. Remarkably, the combined $\mathrm{Sr}-\mathrm{Nd}-\mathrm{Pb}$ data indicate that Centre 3 magmas record no detectable interaction with underlying deep Lewisian gneiss basement, in contrast to Centre 1 and 2 lithologies. This implies that Centre 3 magmas ascended through previously depleted or insulated feeding channels into upper-crustal reservoirs where they resided within and interacted with fertile Moine-type upper crust prior to eruption or final emplacement.
\end{abstract}

Keywords Loch Bà ring-dyke $\cdot$ Centre $3 \cdot$ Isle of Mull $\cdot$ Magma mixing $\cdot$ Magma-crust interaction

Communicated by Gordon Moore.

Valentin R. Troll

valentin.troll@geo.uu.se

1 Department of Earth Sciences, Uppsala University, Villavägen 16, Uppsala, Sweden

2 Neftex, Halliburton, 97 Jubilee Avenue, Milton Park, Abingdon, Oxfordshire OX14 4RW, UK

3 Scottish Universities Environmental Research Centre (SUERC), Rankine Avenue, East Kilbride G75 0QF, UK

4 Department of Earth Sciences, University of Durham, South Road, Durham DH13LE, UK

5 Department of Geological Sciences, University of Stockholm, Svante Arrheniusväg 8C, Stockholm, Sweden

\section{Introduction}

Within the British-Irish Palaeocene Igneous Province, a bimodal distribution of mafic and felsic compositions exists in many intrusive and eruptive suites. This phenomenon frequently raised the question as to the relationship between the respective endmember compositions and a variety of genetic links between coexisting felsic (acidic) and mafic (basic) components have been proposed (e.g. Blake et al. 1965; Walker and Skelhorn 1966; Gamble 1979; Vogel et al. 1984; Sparks 1988; Troll et al. 2004, 2005, 2008a; Emeleus and Bell 2005; Meade et al. 2009, 2014). Whereas traditionally a closed-system relationship has often been favoured, geochemical and particularly isotope studies now suggest that endmember magma compositions in mixed-magma igneous rocks may be more likely to represent replenishments of mafic magmas into felsic magma reservoirs. Centre 3 of the Mull igneous complex (Bailey et al. 1924; Walsh et al. 1979; Figs. 1, 2) 
Fig. 1 Map of the Isle of Mull and surrounding Palaeocene igneous centres (after Fyfe et al. 1993). Ardn. = Ardnamurchan. Also, highlighted are the successive loci of the Mull Igneous Centres 1-3 (yellow stars). Yellow circles mark the sample locations for our crustal sample suite. The small island west of Southern Mull is the Isle of Iona

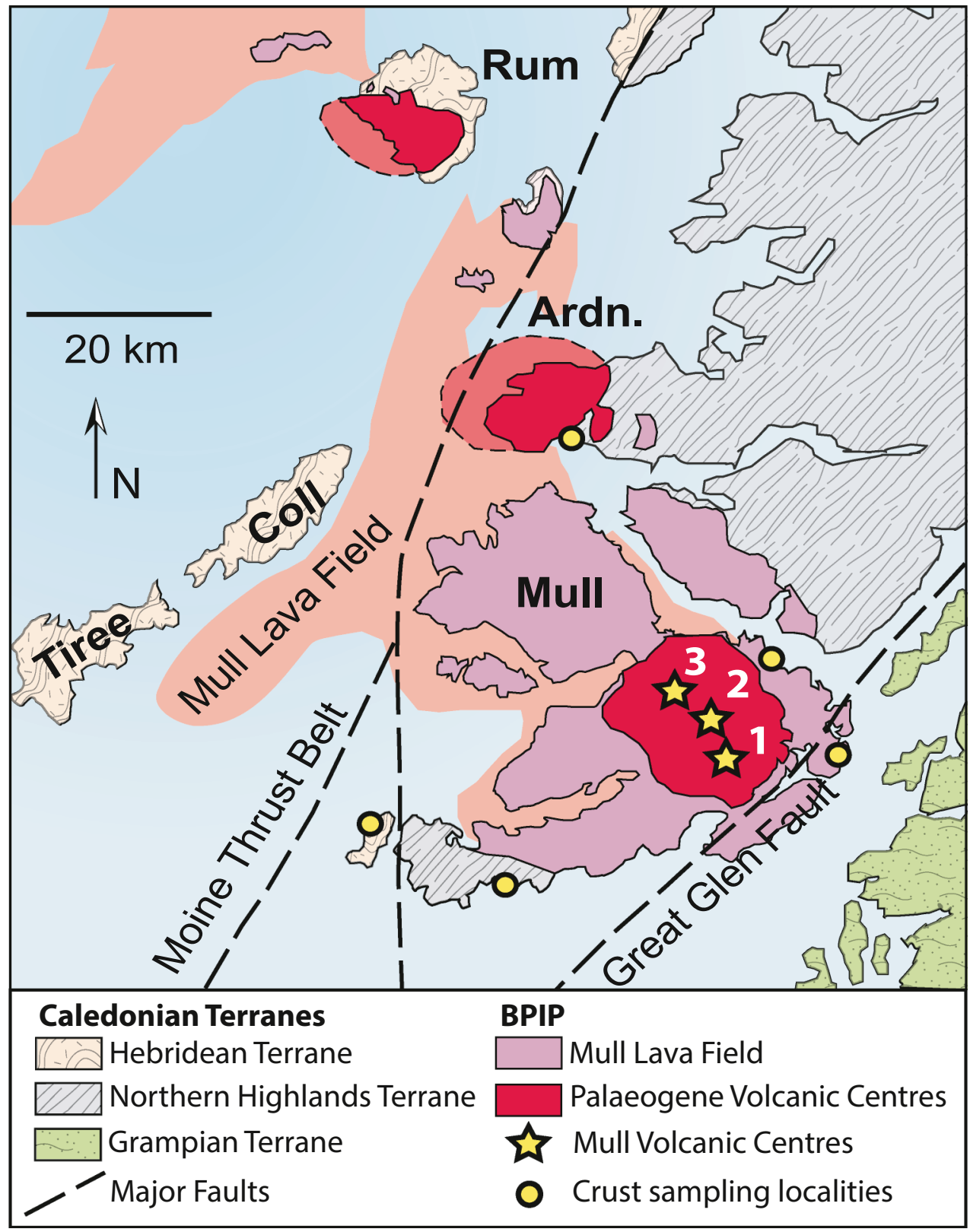

hosts a number of micro-granites (granophyres) and the mixed-magma intrusion of the iconic rhyolite-basalt Loch Bà ring-dyke (Figs. 3, 4, 5). Previous work on the Loch Bà ring-dyke proposed that the mafic and felsic domains represent a closed-system lineage that reflects extreme crystal fractionation within a zoned magma chamber (e.g. Walker and Skelhorn 1966; Sparks and Marshall 1986; Sparks 1988). However, many felsic rocks in the province, have now been recognised to record open system crustal influences in addition to fractional crystallisation processes (e.g. Walsh et al. 1979; Thompson et al. 1982, 1986; Geldmacher et al. 1998, 2002; Troll et al. 2004, 2005, 2019; Font et al. 2008; Meade et al. 2009, 2014; Meyer et al. 2009; Nicoll et al. 2009). Here, we use Sr,
$\mathrm{Nd}$, and $\mathrm{Pb}$ isotopes from selected igneous and crustal rock samples in conjunction with major- and trace-element data to unravel the petrogenetic evolution of the Mull Centre 3 igneous rocks and to test the model of closed-system crystal fractionation for the Loch Bà rhyolites. To the best of our knowledge, we report the first $\mathrm{Nd}$ and $\mathrm{Pb}$ isotope data for the Loch Bà ring-dyke and the associated Centre 3 granites (c.f. Walsh et al. 1979; Kerr et al. 1999). We combine these new data from Centre 3 with existing and new radiogenic isotope data from surrounding crustal lithologies (Fig. 1), which include Moine and Dalradian metasedimentary rocks as well as Iona (Lewisian) gneiss and Iona Group metasedimentary lithologies. 
Fig. 2 Simplified geological map of the Loch Bà Centre (Centre 3) of the Mull Igneous Complex (modified after Emeleus and Bell 2005), showing the Loch Bà ring-dyke and associated granitic intrusions. Thin dashed lines mark a lack of outcrop, but where continuations of the ring dyke are suspected. Thick dashed line marks a presumed early Centre 3 caldera outline

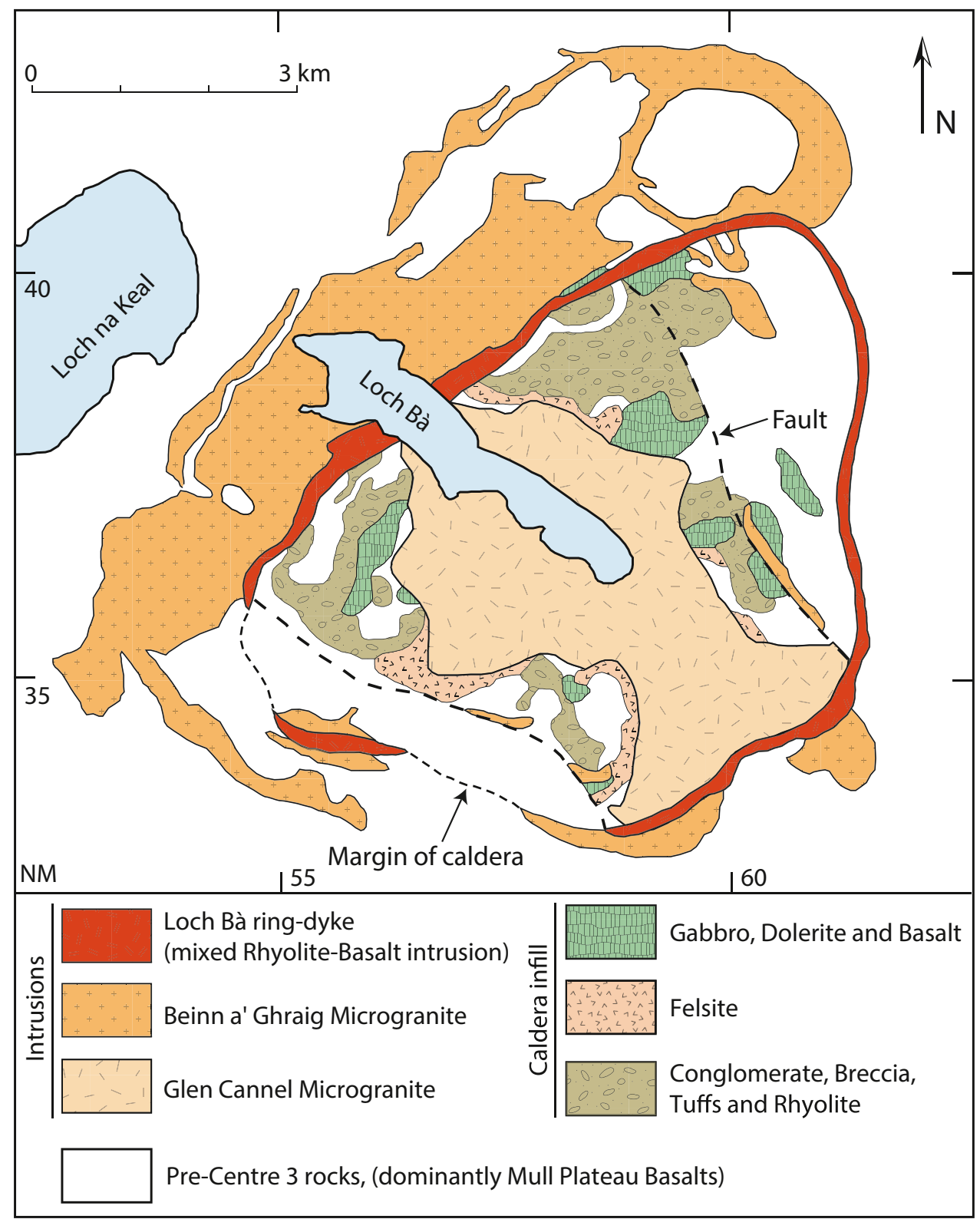

\section{Geological setting}

The Mull Igneous Complex is one of the chains of Palaeocene igneous centres exposed along the West coast of Scotland and in the eastern portion of the northern part of Ireland, and which developed during the early stages of the opening of the North Atlantic (Emeleus and Bell 2005; Troll et al. 2005; Meade et al. 2014). The Mull complex lies within the Northern Highlands Terrane, where Proterozoic Moine metasedimentary rocks make up a large portion of the upper crust beneath the igneous complex (Fig. 1). The rocks of the Northern Highland Terrane are separated from the Hebridean Terrane to the north and west by the shallow southeast-dipping Moine thrust and the Sound of Iona fault (e.g. Smythe 1987; Potts et al. 1995), and it has been suggested that the tectonic transition between Moine schists and Lewisian gneisses occurs at shallow levels beneath Mull and Ardnamurchan (e.g. Bott and Tuson 1973; Bott and Tantrigoda 1987; Kerr et al. 1995, 1999). In the south of Mull, the Moine metasedimentary rocks are separated from Dalradian supergroup metasedimentary lithologies by a continuation of the Great Glen Fault (Bailey et al. 1924), marking the boundary of the Central Highlands (or Grampian) Terrane (Fig. 1).

The Mull Igneous Complex has been the subject of intense geological investigation. Following early pioneering works (see summary in Emeleus and Bell 2005), modern geological investigation commenced with the Mull Memoir 
Fig. 3 a Steep outwarddipping margin of the Loch Bà ring-dyke against the Beinn a' Ghraig granite (left of red arrow), marking the ring-fault of the Centre 3 caldera. b Eutaxitic texture with highly twisted and strung out mafic inclusions (fiamme) that are frequently aligned parallel to the outer margin of the ring-dyke. Lump hammer for scale

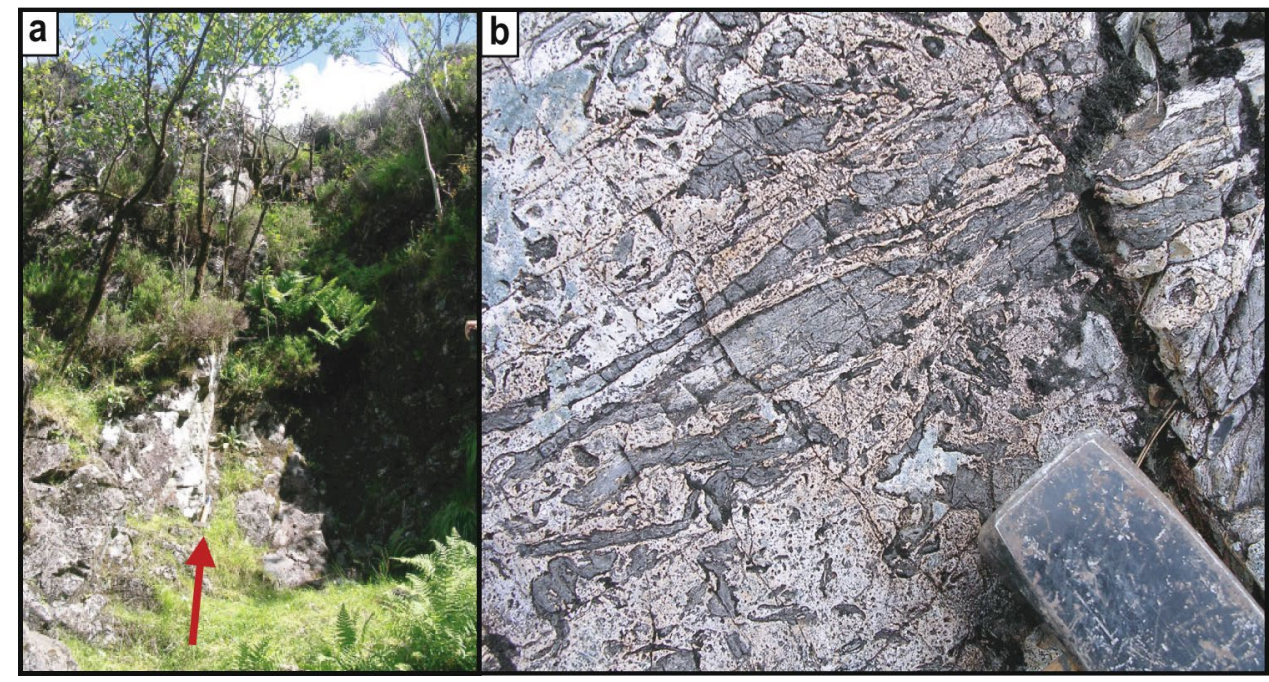

by Bailey et al. (1924). Subsequent works has focussed on the geochemical, textural, and geochronological aspects of the Mull Complex (e.g. Morrison et al. 1985; Thompson et al. 1986; Sparks 1988; Kerr 1993, 1995a, b; Kerr et al. 1995; Preston et al. 1998; Chambers and Fitton 2000; Chambers and Pringle 2001) and a detailed geochemical summary for the evolution of the entire Mull Complex was provided by Kerr et al. (1999). The age and duration of the igneous activity at Mull are constrained between $c .61$ and $58 \mathrm{Ma}$ (Chambers and Pringle 2001; Chambers et al. 2005). Following on after the Staffa lavas, the earliest Palaeocene activity at Mull appears to be the Mull Plateau lavas that have been dated at $60.65 \pm 0.29 \mathrm{Ma}$ (Chambers 2000). The plateau lavas have an estimated total thickness of $\geq 1,800 \mathrm{~m}$ (Bailey et al. 1924) and their geochemistry and stratigraphy have been investigated previously by Beckinsale et al. (1978), Kerr (1995a, b) and Kerr et al. (1995, 1999). There are three geochemically distinct magma types represented within the Mull plateau lavas (Kerr et al. 1999; Chambers and Fitton 2000), reflecting how over time, the depth and style of mantle melting might have changed. The bulk of the Mull Plateau Group lavas is transitional to mildly alkaline basalts, the more magnesium-rich of which are often contaminated with small amounts $(<5 \%)$ of Lewisian crust (Kerr 1995b). These relatively uncontaminated basalts are the result of between 6 and 10\% partial melting of a depleted garnet-bearing mantle source (Kerr 1995a). The Coire Gorm type-lavas (which are of an intermediate age between the Mull Plateau Group and the Central Mull Tholeiites), are somewhat more tholeiitic in nature, and appear to be the products of slightly higher degrees of partial mantle melting (8-12\%) of a spinel lherzolite mantle-source (Kerr 1995a). The youngest lavas on Mull, the Central Mull Tholeiites, are considered the result of the most extensive degree of mantle melting (12-17\%) of a depleted spinel lherzolite mantle (Kerr 1995a, b; Chambers and Fitton 2000).
Contemporaneous with the lavas and in part post-dating them, are the three centres exposed in central Mull. Their loci appear to have migrated in a NW- direction as the Mull Igneous Complex evolved (Fig. 1), with migration from the oldest Glen More Centre (or Centre 1; $59.05 \pm 0.27 \mathrm{Ma}$; Chambers 2000), via the Beinn Chaisgidle Centre (or Centre 2), to the Loch Bà Centre (or Centre 3; 58.48 $\pm 0.18 \mathrm{Ma}$ ) (Chambers and Pringle 2001; Emeleus and Bell 2005). Significant proportions of the exposed rocks within these three centres are of felsic (i.e., granitic, granophyric, and rhyolitic) composition (see Walsh et al. 1979; Kerr et al. 1999), which raises the question as to the relationship of the felsic magmas with the mafic lavas of the complex.

\section{Centre 3 of the Mull Igneous Complex}

We focus here on Centre 3, which marks the closing stages of the main magmatic activity of the Mull Igneous Complex (Fig. 2; Walsh et al. 1979; Kerr et al. 1999). The Glen Cannel Granite (Fig. 5) appears to be the oldest intrusion of Centre 3 and intrudes the basaltic lavas of the Mull Plateau group. It forms an oval, dome-shaped mass with a NW-trending long axis (Bailey et al. 1924; Walsh et al. 1979; Emeleus and Bell 2005). The Glen Cannel Granite is roofed by volcaniclastic rocks and extrusive felsites (rhyolites) preserved within a centrally subsided block enclosed by the Loch Bà ring-dyke, suggesting a caldera type edifice for Centre 3 volcanism (Fig. 2). The Beinn à Ghraig Granite (Fig. 6) is slightly younger than the ring dyke and is located mostly outside the perimeter of the Loch Bà ring-dyke intrusion, but is similar in petrographic character to the Glen Cannel Granite (Emeleus and Bell 2005). The Loch Bà ring-dyke intrusion itself is the youngest of the Centre 3 intrusions and is locally up to $400 \mathrm{~m}$ wide (Fig. 2), but varies in width around 
Fig. 4 a-g Representative thin section photomicrographs of the Loch Bà rhyolite, showing numerous lobate mafic inclusions in a crystal-poor rhyolitic matrix in PPL (specimens LB-1; LB-6 and LB-SE-1). Note, chilling of the mafic enclaves against the rhyolite matrix is not observed, implying the component magmas were approaching thermal equilibrium (cf. Troll et al. 2004)
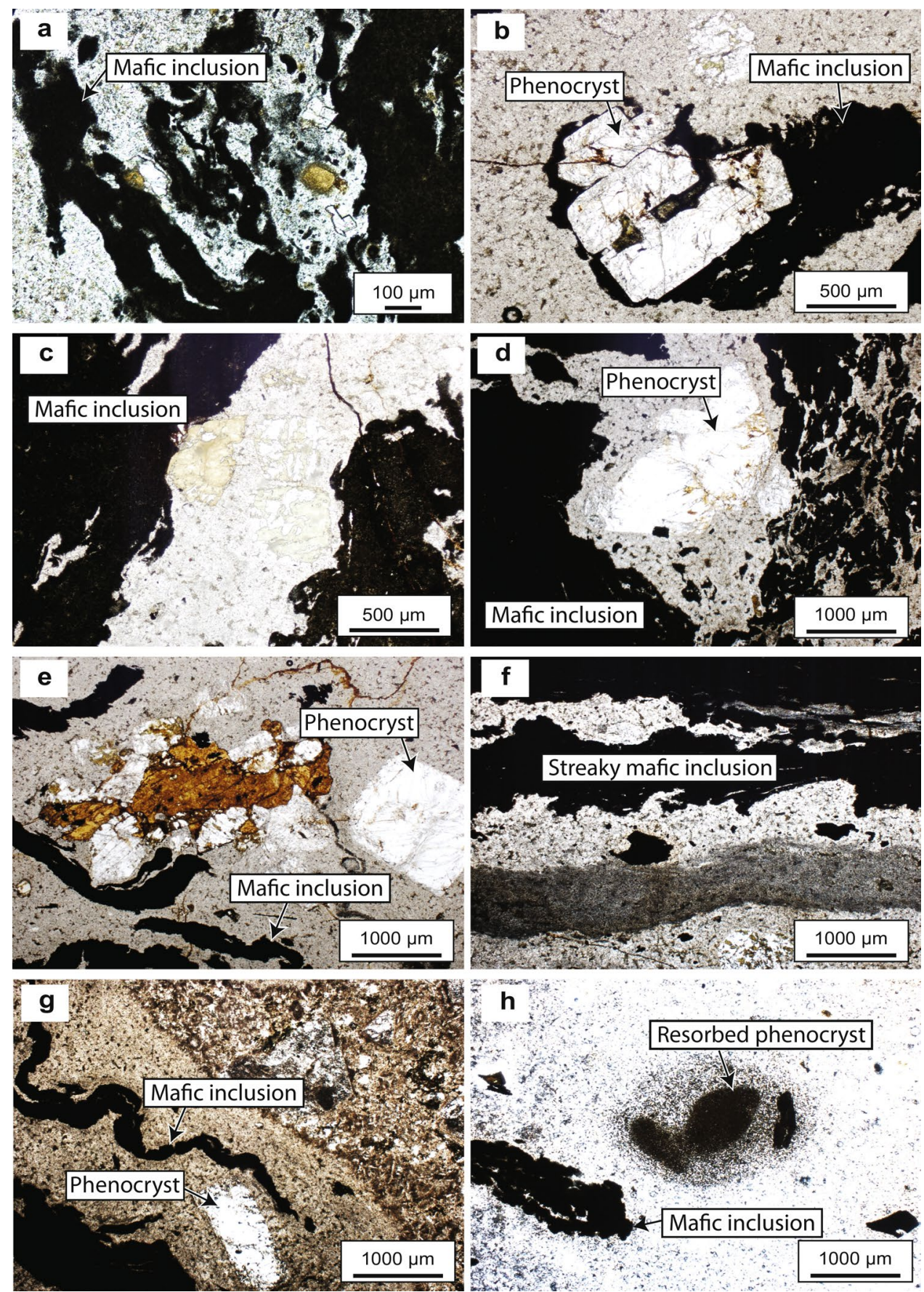

the perimeter of the intrusion. Where exposed, the ring fault is seen to dip steeply outward (Fig. 3) and has been documented to record several hundred metres of vertical displacement (Richey 1932; Lewis 1968). The Loch Bà ring-dyke is characterised by crystal-poor rhyolite that contains abundant streaky basaltic to intermediate mafic inclusions (Walker and Skelhorn 1966; Sparks 1988; Figs. 3, 4; Table 1). The mafic inclusions make up $20 \%$ of the entire rock mass and occur throughout the ring-dyke, but are seen to concentrate locally to form semi-parallel bands, where they exceed 20 vol.\%. The streaky inclusions display fiamme-like shapes, similar to those in welded ignimbrites (Fig. 4). The emplacement of the ring-dyke is thus believed to have involved violent magma fragmentation and mixing of magmas during chamber withdrawal and during conduit transport (Bell and Emeleus 1988; Sparks 1988; Emeleus and Bell 2005). 
Fig. 5 Representative photomicrographs of the Glen Cannel $(\mathbf{a}, \mathbf{c}, \mathbf{e})$ and Beinn à Ghraig (b, d, f) granites of Centre 3 in XPL. Both intrusions show a granophyric texture with abundant symplectitic pockets (e.g. panels e, f), indicating very shallow emplacement and crystallisation
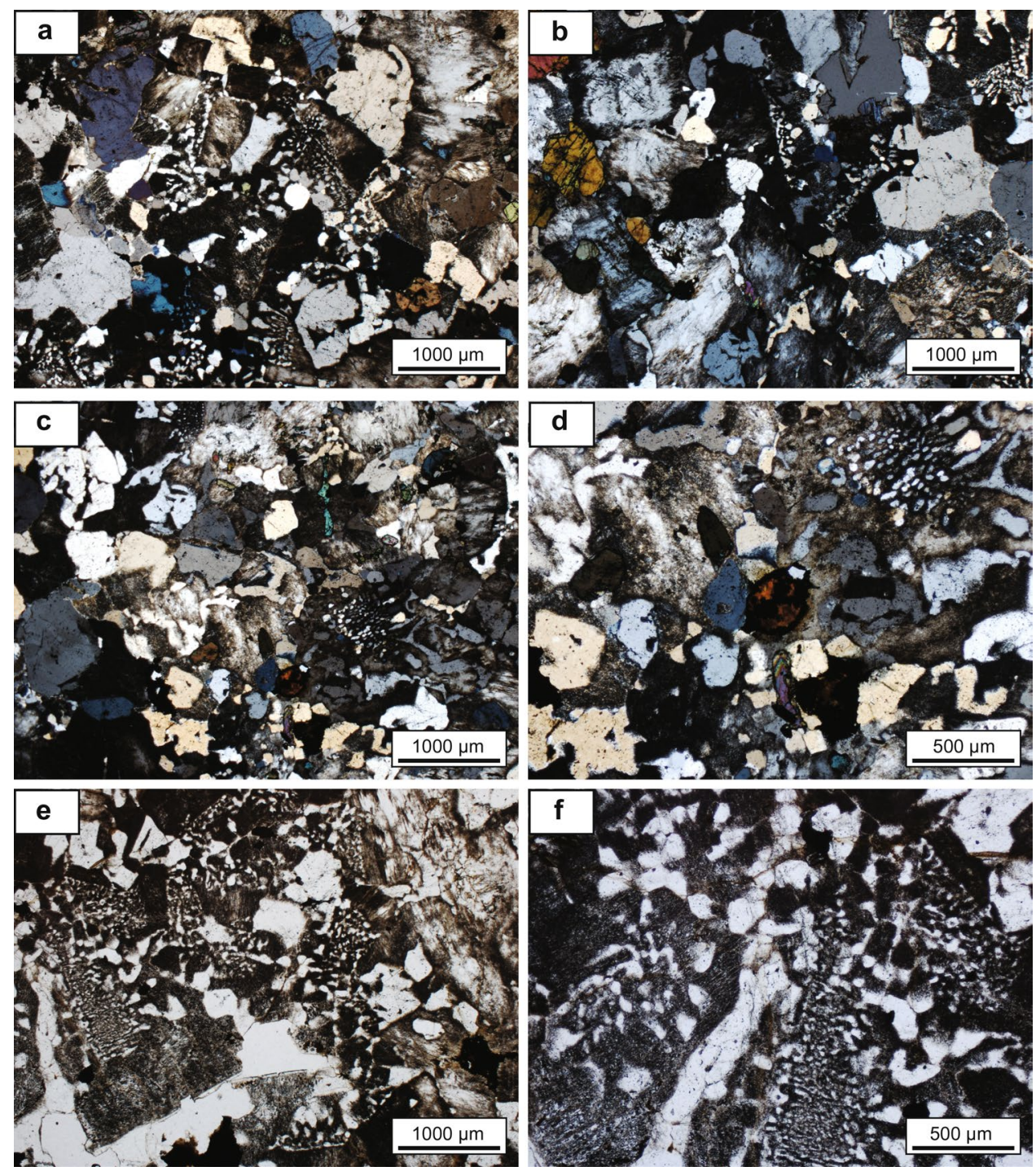

\section{Crustal lithologies}

In addition to Centre 3 igneous rocks, we report new isotope data from Moine metasediments from Mull and nearby Ardnamurchan as well as Dalradian metasedimentary rock samples from the southern tip of the Isle of Mull. In addition, Lewisian gneissic basement and Paleoproterozoic metasedimentary rocks from nearby Iona were also sampled (Tables 2, 3).

The gneiss basement on Iona is unconformably overlain by the Iona Group siliciclastic meta-sedimentary rocks that have traditionally been considered as the offshore equivalent to the Torridonian terrestrial sediments (Potts et al. 1995), while the gneisses are part of the Lewisian Complex (Park 2005). Recent U-Pb detrital zircon and titanite studies (McAteer et al. 2014), however, imply that these siliciclastic meta-sedimentary rocks may potentially have affinities with the Dalradian metasedimentary supergroup on the
Scottish mainland. Both, the Iona gneiss and the Iona Group meta-sedimentary rocks have sub-vertical zones of intense mylonitisation. Potts et al. (1995) argue that the mylonites of Iona are in their original attitude and thus contended that they represent the ductile expression of a NNE trending, steeply inclined extensional fault zone with a down-throw to the ESE that passes through the Sound of Iona. On the basis of this inference, the Iona gneisses and Iona Group metasedimentary rocks would represent the equivalent to the deeper basement beneath the Mull igneous complex that is uplifted on Iona by several kilometres to the level of the Moine Supergroup on Mull (cf. Holdsworth et al. 1994). In addition, we also collected Moine psammite gneisses with pelite partings from the Glenfinnan Division from the core of the Craignure Anticline (across the bay from the ferry port in Craignure), from the eastern side of Ardalanish Bay in SW-Mull (Fig. 1), and from the Ardnamurchan peninsula, near the ferry port, south of Kilchoan. At Ardalanish Bay, a 
Fig. 6 a Total alkali-versussilica (TAS) diagram for Centre 3 rocks from the Isle of Mull. The spread of Centre 3 mafic enclaves and felsic compositions deviates from the evolutionary trends of the Mull lava groups. Mull lava fields after Kerr et al. (1995, 1999). b-h Harker variation diagrams for the Centre 3 rocks. Although some scatter exists in respect to older versus newer data, the linear relationships for iron and titanium oxide, connecting the felsic rocks with the mafic to intermediate Loch Bà inclusions, hints at magma mixing as a relevant process (e.g. Geldmacher et al. 1998; Kerr et al. 1999), while inflections in e.g., $\mathrm{P}_{2} \mathrm{O}_{5}$ vs. $\mathrm{SiO}_{2}$ hint at fractionation processes for e.g. apatite
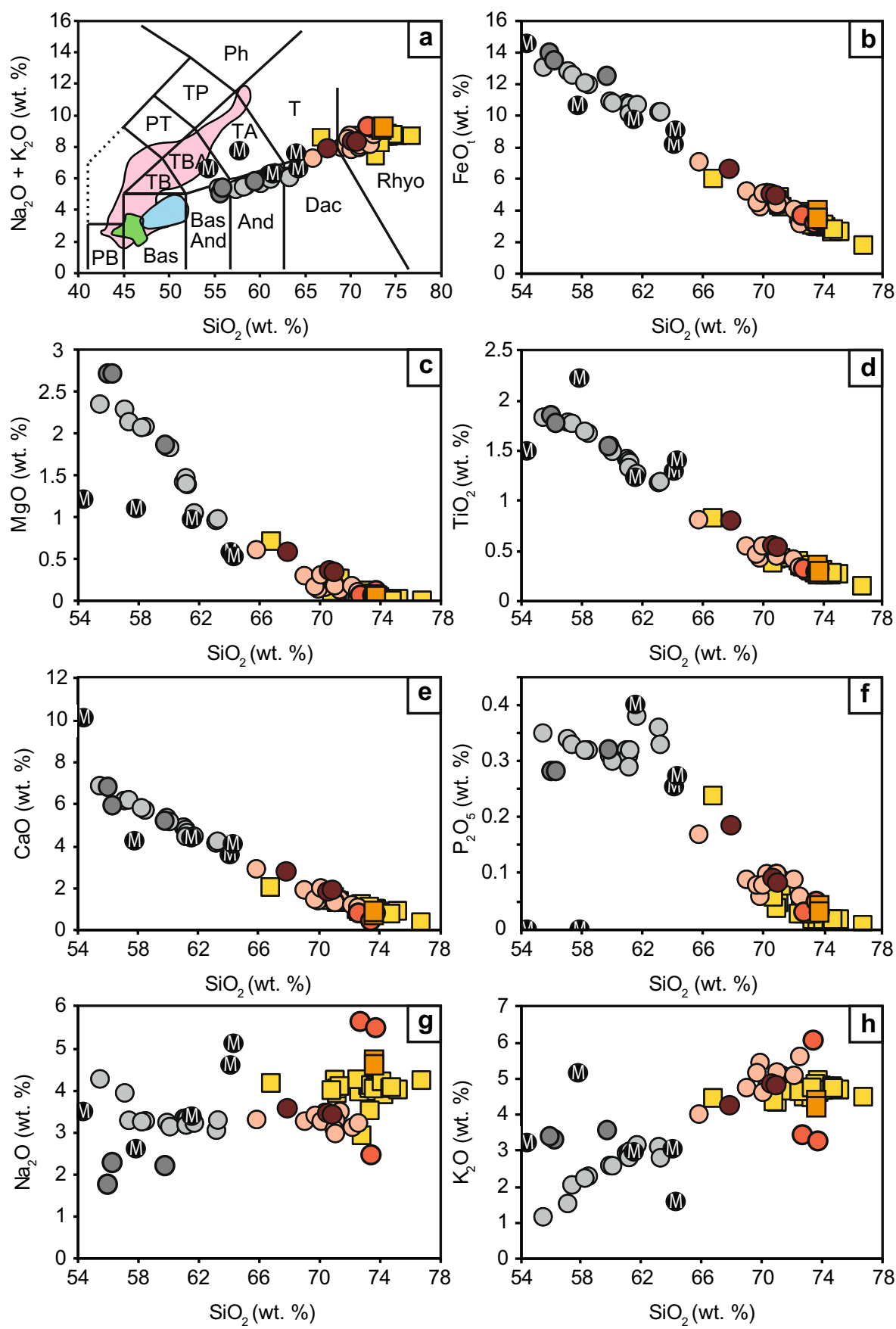

Loch Bà Mafic Inclusions (this study)

Loch Bà Rhyolite groundmass (this study)

Centre 3 Granites (this study)

Coire Gorm Magma-type (Kerr et al. 1995b)

Mull Plateau Magma-type (Kerr et al. 1995b)
Loch Bà Mafic Inclusions (Marshall 1984)

Loch Bà Rhyolite (Marshall 1984)

Loch Bà Mafic Glass (Sparks 1988)

Loch Bà Rhyolite (Sparks 1988)

Centre 3 Granites

(Walsh et al. 1979)

Central Mull Tholeiite

Magma-type (Kerr et al. 1995b) 
Table 1. Representative major (wt.\%), trace and rare-earth element (ppm) concentrations for Mull Centre 3 igneous samples

\begin{tabular}{|c|c|c|c|c|c|c|c|c|}
\hline Rock type & Granite & Granite & Rhyolite & Rhyolite & Rhyolite & $\begin{array}{l}\text { Mafic inclu- } \\
\text { sions }\end{array}$ & $\begin{array}{l}\text { Mafic inclu- } \\
\text { sions }\end{array}$ & $\begin{array}{l}\text { Mafic } \\
\text { inclusions }\end{array}$ \\
\hline Location & $\begin{array}{l}\text { NM } 56732 \\
37322\end{array}$ & $\begin{array}{l}\text { NM } 55238 \\
38155\end{array}$ & $\begin{array}{l}\text { NM } 55666 \\
37416\end{array}$ & $\begin{array}{l}\text { NM } 55444 \\
37489\end{array}$ & $\begin{array}{l}\text { NM } 59252 \\
40126\end{array}$ & $\begin{array}{l}\text { NM } 55216 \\
37035\end{array}$ & $\begin{array}{l}\text { NM } 59387 \\
40372\end{array}$ & $\begin{array}{l}\text { NM } 55482 \\
37417\end{array}$ \\
\hline Sample & Mul-GCG & Mul-BAGG & LB-1 & LB-6 & LB-SE-1 & LB-en-1 & LB-en-2 & LB-en-3 \\
\hline $\mathrm{SiO}_{2}$ & 73.6 & 73.62 & 72.65 & 73.42 & 73.68 & 59.73 & 55.91 & 56.21 \\
\hline $\mathrm{TiO}_{2}$ & 0.36 & 0.3 & 0.33 & 0.29 & 0.33 & 1.54 & 1.86 & 1.78 \\
\hline $\mathrm{Al}_{2} \mathrm{O}_{3}$ & 12.46 & 12.44 & 12.91 & 12.55 & 12.89 & 13.16 & 13.33 & 12.93 \\
\hline $\mathrm{FeO}$ & 3.95 & 3.51 & 3.73 & 3.21 & 3.4 & 12.5 & 14 & 13.54 \\
\hline $\mathrm{MnO}$ & 0.08 & 0.07 & 0.05 & 0.04 & 0.04 & 0.18 & 0.22 & 0.2 \\
\hline $\mathrm{MgO}$ & 0.07 & 0.05 & 0.07 & 0.06 & 0.12 & 1.86 & 2.72 & 2.71 \\
\hline $\mathrm{CaO}$ & 0.91 & 0.73 & 0.82 & 0.47 & 0.82 & 5.19 & 6.84 & 5.96 \\
\hline $\mathrm{K}_{2} \mathrm{O}$ & 4.37 & 4.2 & 3.46 & 6.05 & 3.29 & 3.59 & 3.4 & 3.31 \\
\hline $\mathrm{Na}_{2} \mathrm{O}$ & 4.63 & 4.71 & 5.64 & 2.47 & 5.5 & 2.22 & 1.76 & 2.28 \\
\hline $\mathrm{P}_{2} \mathrm{O}_{5}$ & 0.04 & 0.03 & 0.03 & 0.05 & 0.03 & 0.32 & 0.28 & 0.28 \\
\hline Total & 100.72 & 99.89 & 99.97 & 98.61 & 100.34 & 100.48 & 100.5 & 99.42 \\
\hline LOI & 0.31 & 0.33 & 0.83 & 0.71 & 0.89 & 1.16 & 1.23 & 0.96 \\
\hline Co & 94 & 104 & nd & 131 & 111 & 89 & 121 & 165 \\
\hline $\mathrm{Cr}$ & 3 & 10 & 3 & 11 & 5 & 6 & 14 & 12 \\
\hline $\mathrm{Ni}$ & 1 & 1 & 3 & 1 & $<1$ & 1 & 6 & 1 \\
\hline $\mathrm{V}$ & 7 & 12 & 3 & 5 & 15 & 201 & 318 & 292 \\
\hline $\mathrm{Zn}$ & 97 & 103 & 153 & 75 & 74 & 111 & 123 & 109 \\
\hline $\mathrm{Nb}$ & 37 & 37 & 16 & 29 & 29 & 16 & 11 & 16 \\
\hline $\mathrm{Ga}$ & 25 & 25 & 17 & 21 & 22 & 25 & 25 & 24 \\
\hline $\mathrm{Pb}$ & 17 & 15 & 27 & 26 & 20 & 21 & 19 & 9 \\
\hline $\mathrm{Rb}$ & 171 & 207 & 247 & 224 & 215 & 80 & 79 & 87 \\
\hline $\mathrm{Ba}$ & 935 & 843 & 1123 & 1164 & 1023 & 539 & 346 & 424 \\
\hline $\mathrm{Sr}$ & 47 & 55 & 74 & 78 & 72 & 147 & 162 & 168 \\
\hline Th & 15 & 17 & 5 & 21 & 21 & 15 & 8 & 9 \\
\hline $\mathrm{Y}$ & 87 & 102 & 71 & 82 & 63 & 66 & 56 & 57 \\
\hline $\mathrm{U}$ & 3 & 4 & 1 & 5 & 5 & 3 & 2 & 2 \\
\hline $\mathrm{Zr}$ & 583 & 623 & 489 & 479 & 457 & 292 & 234 & 247 \\
\hline $\mathrm{La}$ & 49 & 48 & nd & 58 & 41 & 39 & 31 & 34 \\
\hline $\mathrm{Ce}$ & 125 & 104 & nd & 116 & 94 & 89 & 67 & 75 \\
\hline $\operatorname{Pr}$ & 14 & 13 & nd & 15 & 11 & 11 & 8 & 9 \\
\hline $\mathrm{Nd}$ & 56 & 54 & nd & 60 & 41 & 43 & 35 & 37 \\
\hline $\mathrm{Sm}$ & 13 & 14 & nd & 13 & 9 & 10 & 8 & 9 \\
\hline $\mathrm{Eu}$ & 2 & 2 & nd & 1 & 1 & 2 & 2 & 2 \\
\hline $\mathrm{Gd}$ & 13 & 14 & nd & 13 & 9 & 10 & 9 & 9 \\
\hline $\mathrm{Tb}$ & 2 & 3 & nd & 2 & 1 & 2 & 1 & 1 \\
\hline Dy & 14 & 17 & nd & 13 & 9 & 10 & 9 & 9 \\
\hline Ho & 3 & 3 & nd & 3 & 2 & 2 & 2 & 2 \\
\hline $\mathrm{Er}$ & 8 & 10 & nd & 8 & 6 & 6 & 5 & 5 \\
\hline $\mathrm{Tm}$ & 1 & 2 & nd & 1 & 1 & 1 & 1 & 1 \\
\hline $\mathrm{Yb}$ & 8 & 10 & nd & 7 & 6 & 6 & 5 & 5 \\
\hline $\mathrm{Lu}$ & 1 & 1 & nd & 1 & 1 & 1 & 1 & 1 \\
\hline
\end{tabular}

Pre-Palaeocene garnet amphibolite intrusion has also been sampled. These mafic intrusions are common within the Glenfinnan and Loch Eil Groups of the Moine Supergroup, but are less frequent in the Morar Group (Strachan et al. 2002). Additionally, grey phyllite of the Appin Group of the (Lower) Dalradian supergroup was collected near Loch 


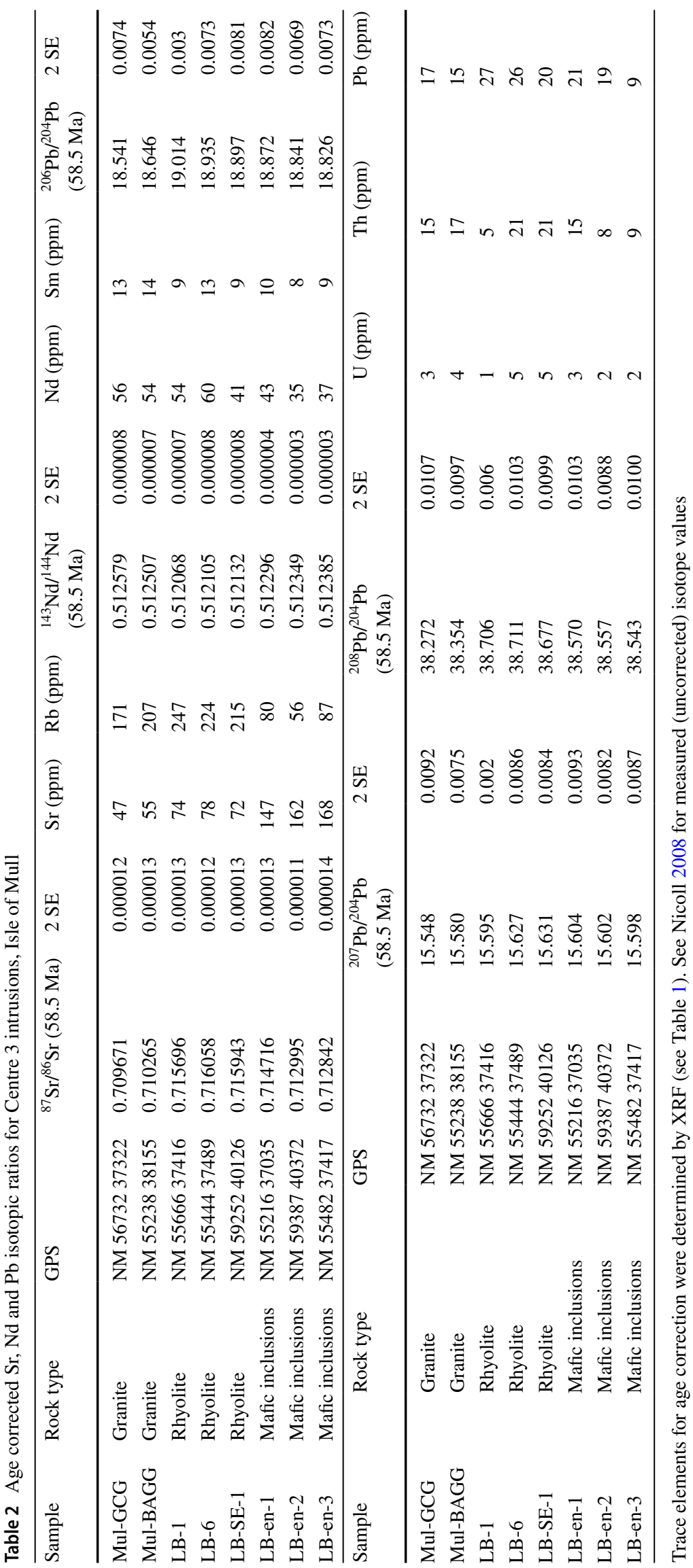




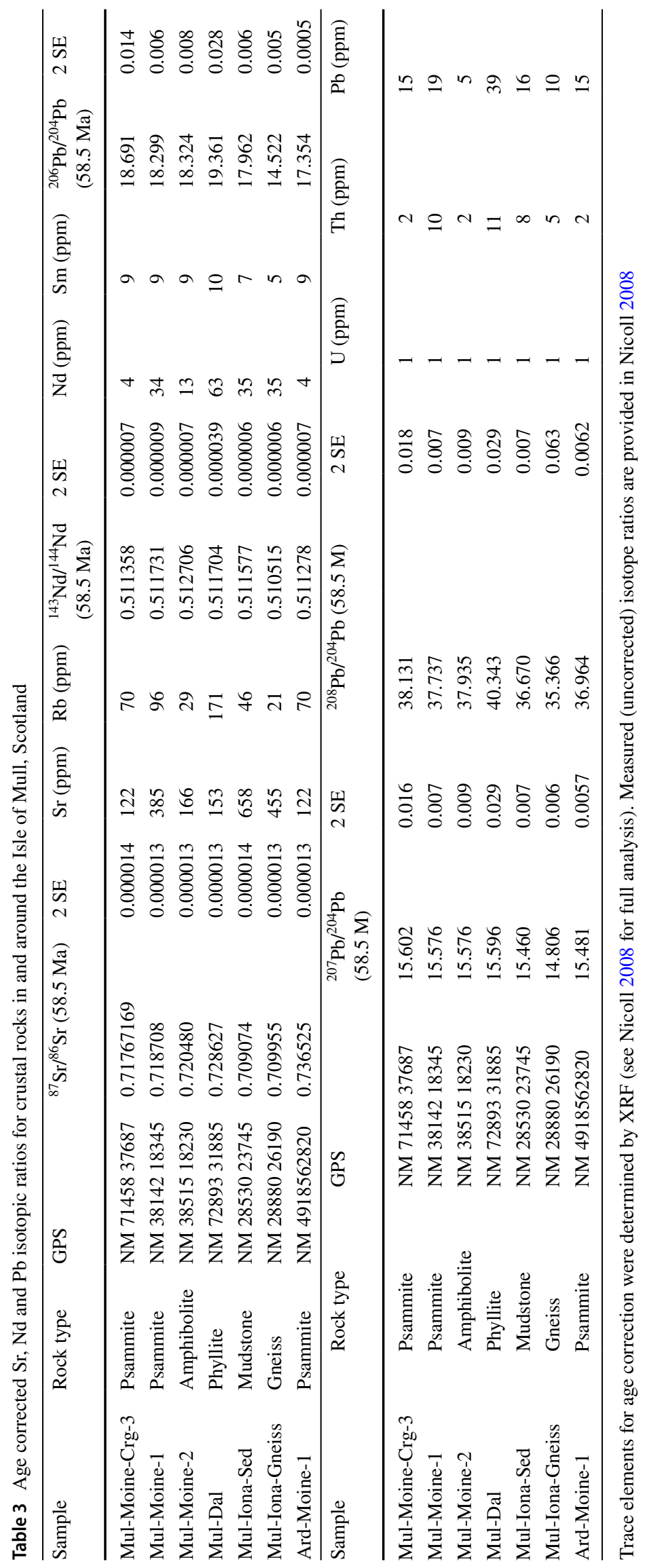


a Ghleannain on south Mull (Fig. 1), in the core of the Loch Don anticline. Several of these crustal divisions have previously not been analysed for their radiogenic isotope compositions making our regional assessment especially timely.

\section{Analytical methods}

To complement existing major and trace-element data on Centre 3 igneous rock samples and crustal compositions in the region, we analysed additional eight igneous and seven crustal rock samples for major and trace elements and for radiogenic isotopes. Samples were crushed in a jaw crusher and then handpicked from fine rock chips. For samples from Loch Bà, the felsic matrix portion was separated from the mafic components by hand using a stereo microscope to ensure end-member compositions are analysed instead of analysing mixed bulk rocks. The mafic Loch Bà samples were extracted from larger mafic inclusions $(\geq 5 \mathrm{~cm})$ that were cut from individual rock samples and then crushed, and also hand-picked under a stereo microscope to avoid felsic materials in the picked sample. Major and traceelement values were determined using X-ray fluorescence spectrometry (XRF) on fused beads, employing an automated Philips PW1480 spectrometer at GEOMAR Research Center in Kiel, Germany following the procedure outlined in Troll and Schmincke (2002) and with full analytical details given in Abratis et al. (2002). The rare-earth element concentrations were determined by inductively coupled plasma mass spectrometry (ICP-MS), using an Agilent 7500 CE, at the Scottish Universities Environmental Research Centre (SUERC), East Kilbride, Scotland and $\mathrm{Sr}-$, Nd-, and $\mathrm{Pb}-$ isotope analyses were also conducted at SUERC. Radiogenic isotopes for $\mathrm{Sr}$ and $\mathrm{Nd}$ were analyzed on a VG Sector 54-30 thermal ionization mass spectrometer. ${ }^{87} \mathrm{Sr} /{ }^{86} \mathrm{Sr}$ was corrected for mass fractionation using ${ }^{86} \mathrm{Sr} /{ }^{88} \mathrm{Sr}=0.1194$. Repeat analysis of the NIST SRM-987 Sr standard gave $0.710257 \pm 18$ ( $2 \mathrm{sd}, n=14$ ) for the duration of this study (see Meyer et al. 2009; Troll et al. 2019 for full analytical details). ${ }^{143} \mathrm{Nd} /{ }^{144} \mathrm{Nd}$ was corrected for mass fractionation using ${ }^{146} \mathrm{Nd} /{ }^{144} \mathrm{Nd}=0.7219$. During the course of this study, the SUERC internal Nd laboratory standard (JM), which is calibrated against the La Jolla Nd solution and the JNdi-1 standard, gave ${ }^{143} \mathrm{Nd} /{ }^{144} \mathrm{Nd}=0.511511 \pm 9(2 \mathrm{sd}, n=21) . \mathrm{Pb}$ was separated using standard $\mathrm{HBr}-\mathrm{HCl}$ anion exchange techniques, and measured on a Micromass IsoProbe MC-ICPMS. The data were corrected for mass fractionation of $0.1 \%$ amu-1 based on replicate analysis of the NBS-981 standard. External reproducibility of the ${ }^{206} \mathrm{~Pb} /{ }^{204} \mathrm{~Pb},{ }^{207} \mathrm{~Pb} /{ }^{204} \mathrm{~Pb}$ and ${ }^{208} \mathrm{~Pb} /{ }^{204} \mathrm{~Pb}$ isotopic ratios is $0.2 \%$ (2 sd), and analytical blanks were $<1 \mathrm{ng}$ (see Fitton et al. 1998; Ellam 2006; Meyer et al. 2009 for full analytical details). All isotope ratios were age-corrected to $58.5 \mathrm{Ma}$ according to the accepted time of igneous emplacement (Chambers and Pringle 2001).

\section{Results}

\section{Major-, trace- and rare-earth elements}

We compare our new major and trace-element data from the Centre 3 Loch Bà ring-dyke and its mafic inclusions as well as from the Beinn à Ghraig and the Glen Cannel microgranites (see Figs. 6, 7, 8; Table 1) with available data from previous investigations (Marshall 1984; Sparks and Marshall 1986; Sparks 1988; Kerr et al. 1999). On a TAS diagram (Fig. 6a), our felsic Centre 3 igneous rocks show very similar compositions and form a tight high-silica cluster $\left(\mathrm{SiO}_{2} 72.5\right.$ to 74 wt.\%). Similarly, on most Harker plots (Fig. 6b-h), previous whole-rock data are more spread out than our handpicked endmember compositions, implying mixing between mafic and felsic compositions, especially as characteristic inflections expected for mineral fractionation are not always present (e.g. for iron and titanium), although some oxides do show inflections (e.g., phosphorus). Exceptions are $\mathrm{K}_{2} \mathrm{O}$ and $\mathrm{Na}_{2} \mathrm{O}$ that show a degree of scatter and can reach up to $6 \mathrm{wt} . \%$ in the Loch Bà rhyolite samples. Although we cannot exclude a degree of alteration for some of the literature samples, the LOI values of our samples were consistently low (Table 1), and the values derived for our samples are thus unlikely to be the result of secondary alteration, but must reflects the highly evolved nature of the crystal-poor Loch Bà rhyolite magma (Fig. 6). In respect to trace elements, less data are available from previous studies, making it all the more obvious that the Centre 3 granites differ from the Loch Bà rhyolite, likely because of modal mineral variations (Figs. 4, 5, 7). Moreover, the mafic Loch Bà ring-dyke inclusions are compositionally separate from the felsic Centre 3 rocks, defining a compositional gap. The mafic samples also appear to show a spread from basaltic-andesite to andesite $\left(\mathrm{SiO}_{2}\right.$ from 56 to $\sim 60 \mathrm{wt} . \%$ and $\mathrm{MgO}$ from 1.8 to 2.7 wt.\%) and notably, no pure basalt is found amongst the more mafic enclaves. In fact, they have relatively low $\mathrm{Ni}$, in line with the low $\mathrm{MgO}$ values, and they are thus typical for intermediate magmatic compositions from the region (cf. Emeleus and Bell 2005; Troll et al. 2019).

Chondrite-normalised (after Boynton 1984) REE concentrations of our Centre 3 samples show all of the samples are enriched in LREE relative to primitive mafic compositions from Mull and from the wider region (Fig. 8). Centre 3 samples display negative Eu anomalies with $\mathrm{Eu} / \mathrm{Eu}^{*}=0.43-0.51$ for felsic samples and 0.58-0.68 for the mafic Loch Bà inclusions. The Loch Bà rhyolites display a slightly more pronounced Eu-anomaly relative to the Centre 3 granite samples, consistent with a more evolved (crystal poor) 
Fig. 7 Selection of trace element concentration plots of our new data versus $\mathrm{SiO}_{2}$ and $\mathrm{Zr}$ ppm. Note that two distinct clusters are defined for $\mathrm{SiO}_{2}$, while $\mathrm{Zr}$ (ppm) concentrations are more spread out, likely reflecting progressive magma mixing for the Loch Bà ringdyke compositions (cf. Gamble 1979; Troll et al. 2004). Additional data for Centre 3 granites where available are from Walsh et al. (1979)
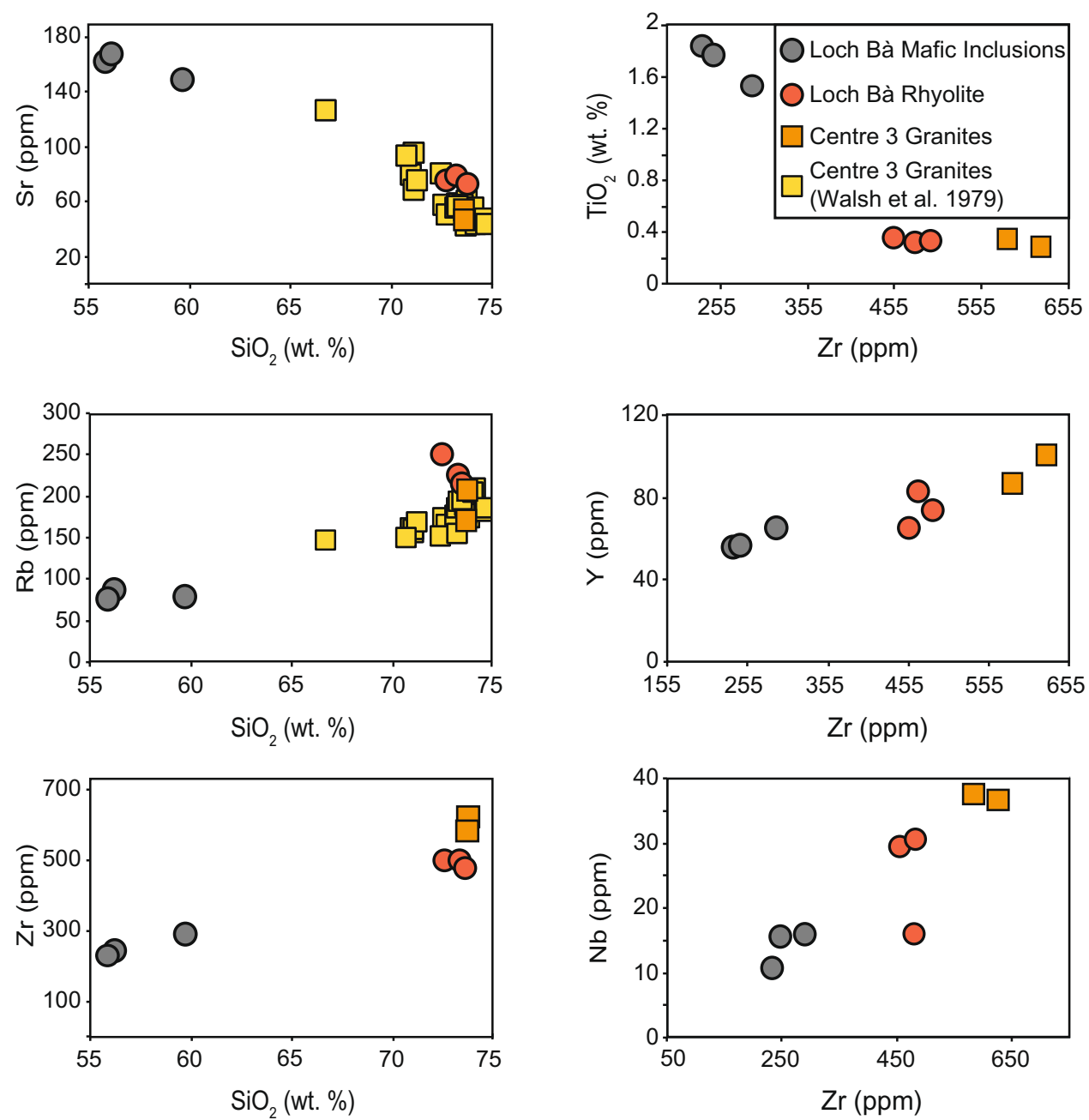

composition. There is overall, however, limited difference in the REE concentrations between the Loch Bà mafic inclusions and the Loch Bà rhyolite, nor in fact between Loch Bà samples and the Centre 3 granites, and all of the samples broadly overlap in their REE spectra (Fig. 8). Remarkably, the REE patterns from the Centre 3 igneous samples are also very similar to those of local Moine pelitic schists (cf. Geldmacher et al. 1998), which would thus appear to have had a compositional influence on the Centre 3 igneous suite, consistent with the isotope data we present below.

\section{Isotope composition of crustal samples}

Isotope data of crustal lithologies are reported in Table 3 and all our crustal samples are markedly displaced from mantle-like compositions. The age-corrected data (at 58.5 Ma) show a large range of isotopic compositions. Crustal samples from different terranes or units are clearly discernible from each other in isotope space (Fig. 9), and thus they provide a framework for us to resolve specific crustal influences the Centre 3 magmas may have experienced.
Specifically, the Iona gneiss shows comparatively low ${ }^{87} \mathrm{Sr} /{ }^{86} \mathrm{Sr}$ and ${ }^{143} \mathrm{Nd} /{ }^{144} \mathrm{Nd}$ isotope ratios and plot between the previously defined Lewisian amphibolite- and granulite-facies fields (Dickin 1981; Dickin et al. 1984). The Iona Group metasedimentary rock, in turn, shows elevated ${ }^{143} \mathrm{Nd} /{ }^{144} \mathrm{Nd}$ ratios (Figs. 9, 10), whereas the Iona gneiss plots towards less radiogenic $\mathrm{Pb}$ isotope ratios relative to the Iona Group metasedimentary rocks, highlighting that the latter is not purely derived from the former in terms of sedimentary provenance (e.g. McAteer et al. 2014).

Available data for the Moine metasedimentary rocks show a large spread in isotope values (e.g. Thompson et al. 1986; Preston et al. 1998), which overlap with our new Moine isotope data (Table 3). Moine samples from Ardnamurchan (e.g., Geldmacher et al. 1998, 2002) are more radiogenic in terms of ${ }^{87} \mathrm{Sr} /{ }^{86} \mathrm{Sr}$ than our Moine samples from Mull (Figs. 9, 10). For Sr and Nd isotopes, our Dalradian sample plots within the large Moine field, whereas for $\mathrm{Pb}$-isotopes the Dalradian sample plots close to the Moine and the Iona metasedimentary suites (Figs. 9, 10, 11). 
Fig. 8 Chondrite-normalised rare-earth element (REE) diagram (normalized after Boynton 1984) for the Centre 3 igneous samples of this study, Moine schist (from Geldmacher et al. 1998), representative mid-range samples of the Mull Magma types (from Kerr et al. 1999), Loch Scridain sills (Preston et al. 1998), the gneisses from Iona and Tiree (Walsh et al. 1979; Kerr et al. 1995), and picrite dyke M9 (Upton et al. 2002). Symbol sizes are larger than associated analytical uncertainties. Note Pm (between $\mathrm{Nd}$ and $\mathrm{Sm}$ ) is not included. The Centre 3 samples show surprisingly similar REE patterns to the local Moine-type crust (see also Preston et al. 1998). See text for details

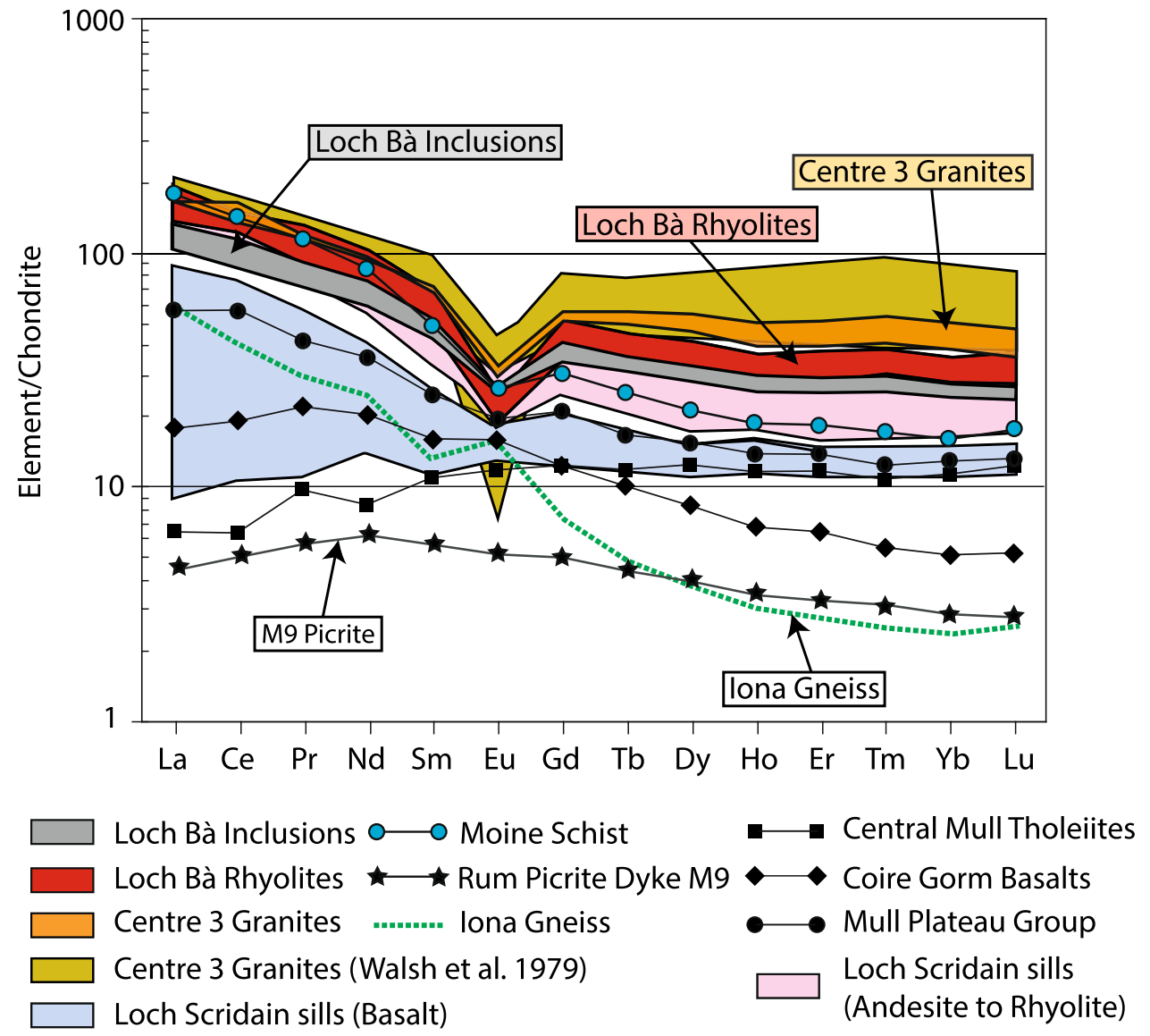

\section{Isotope geochemistry of centre 3 igneous rocks}

The isotope data of the Centre 3 igneous rocks are plotted in Figs. 9, 10, 11 and 12. All Centre 3 granite and rhyolite samples are markedly enriched in ${ }^{87} \mathrm{Sr}^{86} \mathrm{Sr}_{\mathrm{i}}(0.709$ to 0.716$)$ relative to mantle-type compositions and show a spread in ${ }^{143} \mathrm{Nd} /{ }^{144} \mathrm{Nd}_{\mathrm{i}}(0.51258-0.51207)$. They are significantly displaced towards the Moine metasedimentary rocks of the local upper crust. Notably, the Loch Bà rhyolites and mafic inclusions are the most radiogenic of the analysed suite, and are considerably more radiogenic than the Centre 3 microgranites. This relationship precludes a closed-system magmatic evolution for the various Centre 3 magmas (e.g. Sparks et al. 1988) and documents open system assimilation of Moine-type country-rock (e.g. Walsh et al. 1979).

Although, there is only a narrow range of values obtained from our Centre 3 igneous samples, the Centre 3 igneous rocks also show extremely radiogenic $\mathrm{Pb}$-isotope ratios relative to mantle proxies (cf.Ellam and Stuart 2000; Upton et al. 2002; Ellam 2006) and a crustal influence can be clearly resolved (Figs. 9, 10, 11, 12). Pb-isotopes therefore confirm the ${ }^{87} \mathrm{Sr} /{ }^{86} \mathrm{Sr}$ and ${ }^{143} \mathrm{Nd} /{ }^{144} \mathrm{Nd}$ results, showing a substantial Moine crustal contribution to the Centre 3 magmas. Notably, the Loch Bà rhyolites are also the most radiogenic samples of the Centre 3 Suite in respect to $\mathrm{Pb}$ isotopes.

\section{Discussion}

\section{Major and trace elements}

The Centre 3 micro-granites and the Loch Bà rhyolites form a high $\mathrm{SiO}_{2}$ cluster on most major and trace-element plots (Figs. 6, 7), whereas the Loch Bà mafic inclusions spread out in the intermediate compositional range. Using our handpicked end-member samples for the enclaves and the Loch Bà rhyolites, we note that a pronounced compositional gap (Bunsen-Daly gap) becomes apparent between these groups, for major elements as well as for trace elements, which was not as obvious from the previous studies where bulk samples were used (cf. Fig. 6). Moreover, the linear trend for the previously published Loch Bà data suite in e.g., $\mathrm{TiO}_{2}$, $\mathrm{FeO}_{\mathrm{t}}$, against $\mathrm{SiO}_{2}$ is likely a function of magma mixing between the Loch Bà rhyolite and mafic magma(s), as the characteristic 'kinks' of fractional crystallisation are not observed on these graphs (cf. Geldmacher et al. 1998; Kerr et al. 1999; Troll et al. 2004). Indeed, all Centre 3 samples 


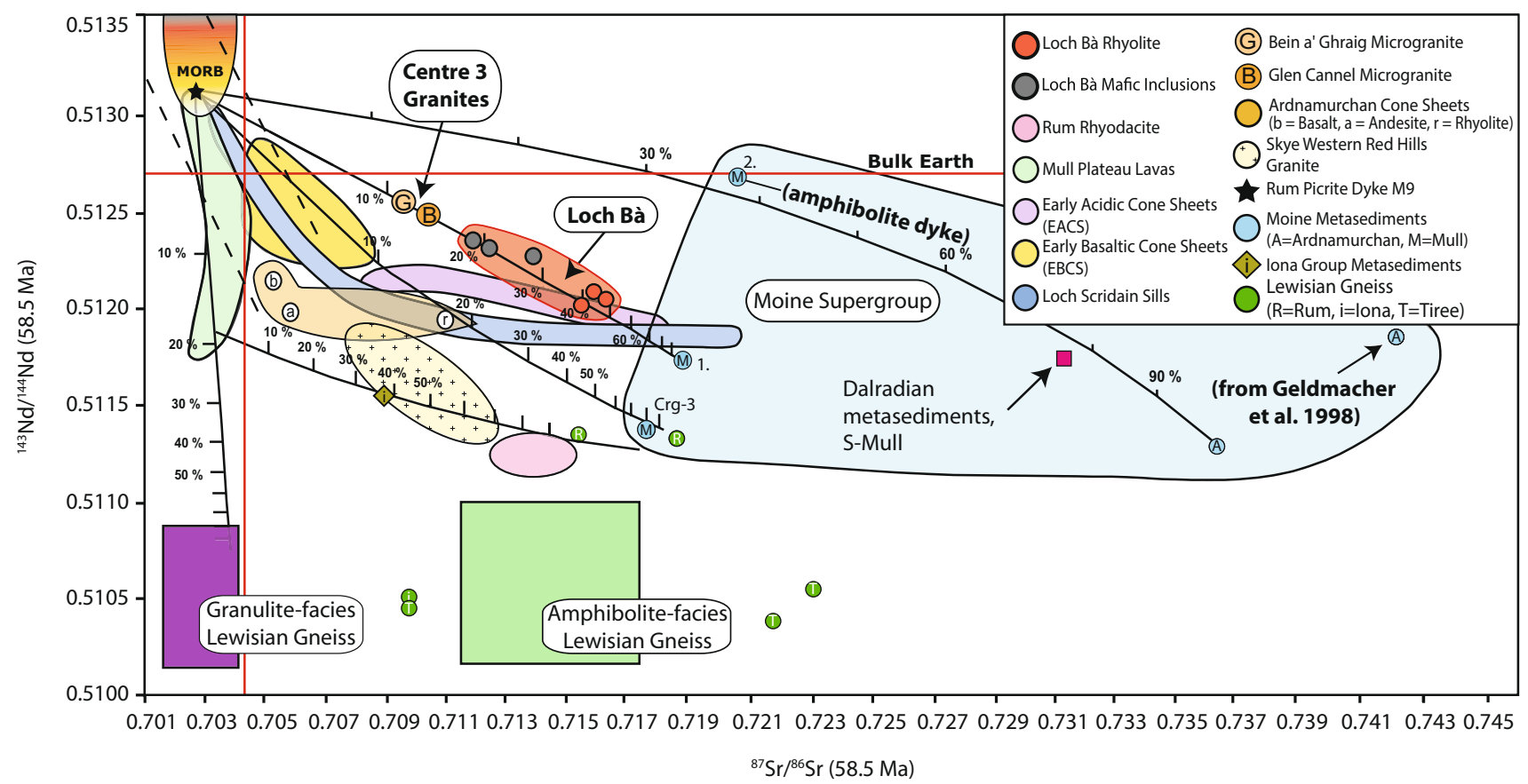

Fig. $9{ }^{87} \mathrm{Sr} /{ }^{86} \mathrm{Sr}$ vs. ${ }^{143} \mathrm{Nd} /{ }^{144} \mathrm{Nd}$ diagram for our Mull Centre 3 and crustal lithology samples. Also shown are the Loch Scridain sills (Preston et al. 1998), the Mull lava and cone sheet data (Thomson 1986; Kerr et al. 1999), the Ardnamurchan cone-sheet data and Ardnamurchan Moine crust (Geldmacher et al. 1998), the Skye Red hills data (Dickin et al. 1981), and gneiss from Tiree (Kerr et al. 1995). The associated analytical uncertainty is smaller than the size of the

are also significantly LREE enriched relative to mantle-like compositions and seem to share a strong trace-element affinity with the Moine pelite schists (Fig. 8), i.e., they mirror a strong enrichment of La to Sm (cf. Thompson et al. 1986). Moreover, all Centre 3 rocks show negative Eu anomalies $\left(\mathrm{Eu} / \mathrm{Eu}^{*}=0.43-0.68\right)$, which may reflect plagioclase fractionation, or, more probably, selective crustal melting of Moine rocks that left behind a plagioclase-rich restite (cf. Walsh et al. 1979; Duffield and Ruiz 1998), which together with the La and Sm enrichment is thus unlikely to reflect crystal fractionation. Interaction between Centre 3 magmas with Iona Lewisian gneiss cannot be fully ruled out, but Moine-type rocks were clearly the dominant crustal influence on the REE patterns of the felsic Centre 3 magmas. A virtually continuous spectrum of phenocryst compositions was reported in the Loch Bà suite by Sparks (1988) and was interpreted to reflect a continuous liquid line of descent. This, he argued, supports continuous fractional crystallisation as in a Skaergaard-type scenario (e.g. McBirney 1975). The presented REE data, together with the new isotope results rule out a closed-system evolution, however, implying magma-crust interaction as an important process during the evolution of Centre 3 magmatic compositions (cf. Walsh et al. 1979). data symbols. Our new crustal data and previously established reference fields for crustal compositions in the region indicate that the Centre 3 samples seem to follow a contamination trajectory from primitive mantle towards Moine-type crustal compositions, and lack obvious deviations towards lower crustal (Lewisian) influences. Binary mixing trajectories of mantle-derived basalt magma with key crustal units are indicated by solid lines (see text for details)

\section{Isotopes}

Iona Lewisian gneisses and Iona Group metasedimentary rocks are isotopically distinct from each other (Figs. 9, 10, 11, 12). The Iona gneiss shares characteristics with granulite- and amphibolite-type Lewisian gneisses exposed farther north on the Scottish mainland and on Tiree (Dickin 1981; Kerr et al. 1995; Friend and Kinny 2001; Kinny et al. 2005). However, neither REE data (Walsh et al. 1979) nor the isotope data of this study show that Iona gneiss or the Iona Group metasedimentary rocks left a significant imprint on the Centre 3 igneous rocks (Figs. 9, 10, 11, 12). In contrast, earlier rocks from the Mull igneous complex, e.g. Mull Plateau lavas and cone-sheets of Centre 1, do clearly record signs for interaction with Lewisian-type materials (Thompson et al. 1986; Kerr 1995a, b; Preston et al. 1998; Kerr et al. 1999). In addition, isotope modelling (Figs. 11, 12), suggests that Dalradian metasediments have also not significantly contributed to the Centre 3 magma compositions, which is not unreasonable given the centre's position north of the Great Glen fault and the $>20 \mathrm{~km}$ geographical distance between Centre 3 and the nearest occurrence of Dalradian rocks in outcrop. The Moine Supergroup is seemingly the only significant crustal influence on Centre 3 rocks 
Fig. $10 \mathrm{a}^{206} \mathrm{~Pb} /{ }^{204} \mathrm{~Pb}$ vs. ${ }^{207} \mathrm{~Pb} /{ }^{204} \mathrm{~Pb}$ and $\mathbf{b}{ }^{206} \mathrm{~Pb} /{ }^{204} \mathrm{~Pb}$ vs. ${ }^{208} \mathrm{~Pb} /{ }^{204} \mathrm{~Pb}$ correlation diagrams for our Mull Centre 3 samples and regional reference samples (sources as in Fig. 9). Symbol size is larger than associated analytical errors. The Centre 3 igneous samples fall all into the Moine crustal field and are considerably removed from the mantle area of the diagram. This implies open system behaviour involving dominantly Moine-type country-rocks, which points to storage and emplacement in the shallow crust (see text for details)

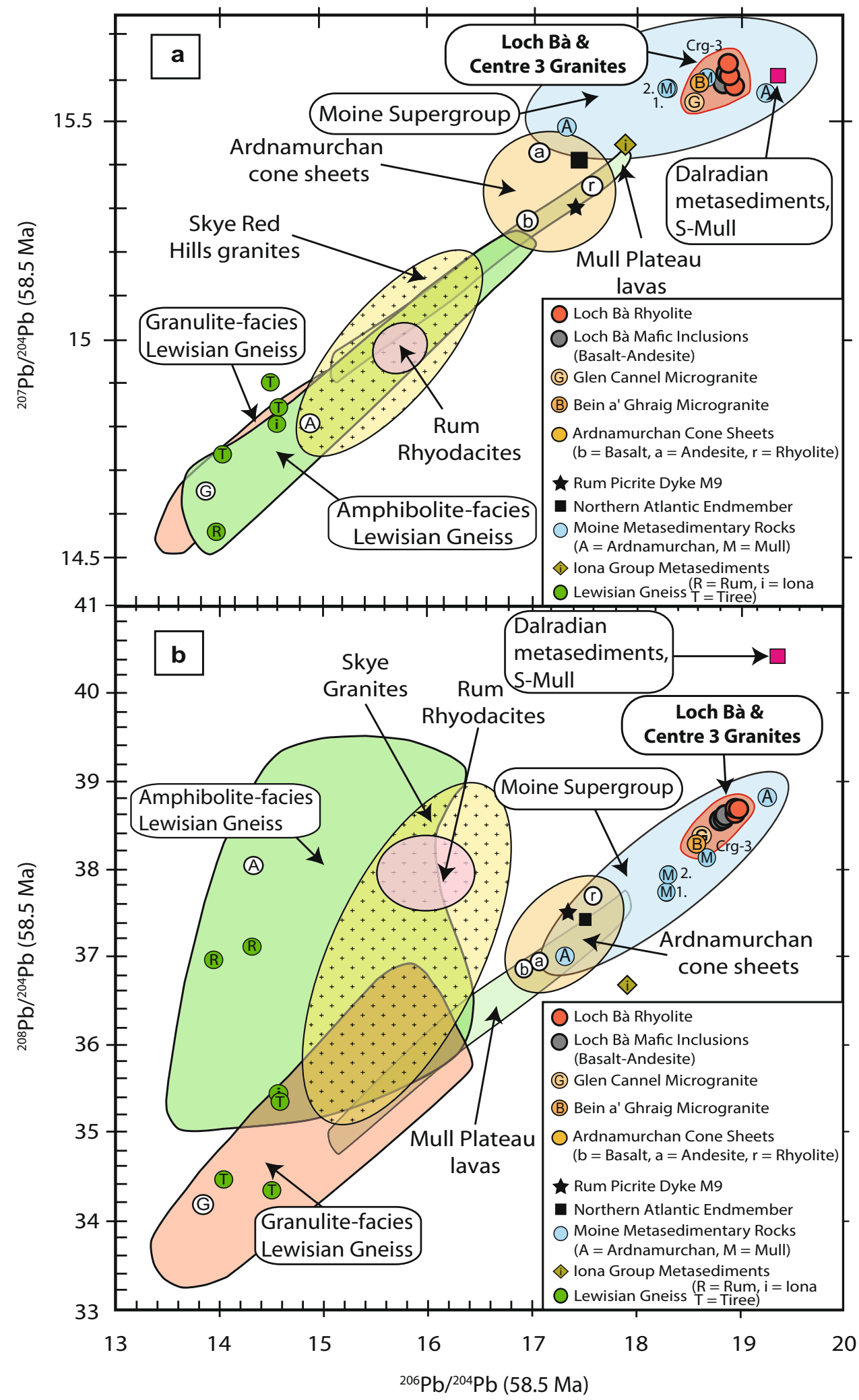

and although small early additions of Lewisian cannot be ruled out, the mixing trajectories shown in Fig. 9 preclude large amounts of Lewisian gneiss materials to have played a role. The Moine Supergroup suite is divided into three stratigraphic subunits (Strachan et al. 2002). The oldest Morar Group is exposed on Ardnamurchan (e.g. Geldmacher et al. 


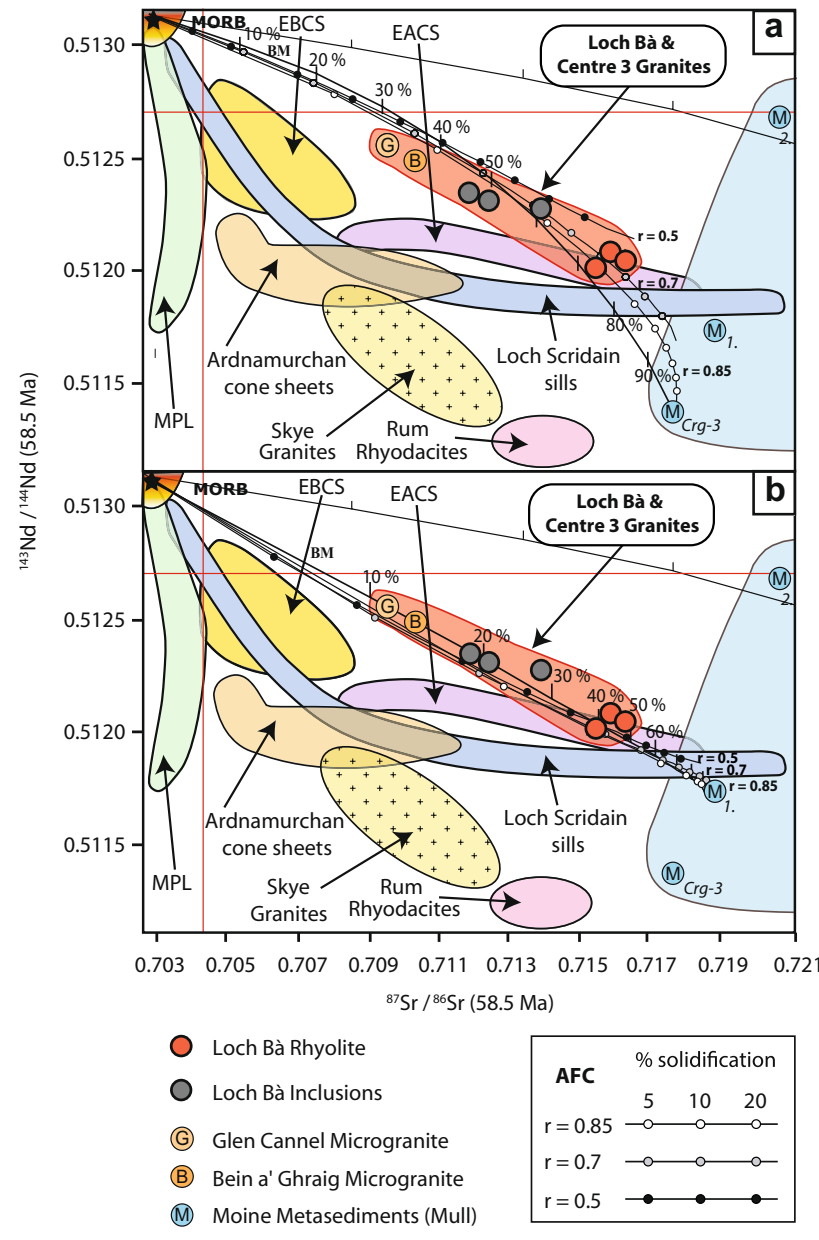

Fig. $11{ }^{87} \mathrm{Sr} /{ }^{86} \mathrm{Sr}$ vs. ${ }^{143} \mathrm{Nd} /{ }^{144} \mathrm{Nd}$ plots for the Mull Centre 3 samples with added AFC-trajectories and binary mixing curves (BM) between a MORB-type parental 'Hebridean' magma and Moine-type country rocks (Mul-Moine-1 and Mul-Moine-CRG-3). Reference samples as in previous figures. The $\mathrm{r}$ value is the ratio of assimilation relative to the amount of fractionation (AFC and binary mixing calculations from Nicoll 2008). a AFC trajectories involving crustal Moine samples Mul-Moine-CRG-3 (see Table 3). b Same plot using a different Moine composition as dominant contaminant (Mul-Moine-1). In either case, the AFC and binary mixing calculations support an apparent absence of deep basement influences for Centre 3 compositions, contrasting e.g. the Mull Plateau Group lavas (MPL), the early acidic cone-sheets (EACS), the early basaltic cone-sheets (EBCS), and the Loch Scridain sills (Thomson 1986; Preston et al. 1998)

1998), while the younger (but higher metamorphic grade) Glenfinnan Group is exposed in SW- and E-Mull. From the Moine isotope data obtained in this study, it seems these groups can be broadly distinguished on isotopic grounds (e.g. using $\mathrm{Sr}-\mathrm{Nd}$ isotope ratios, Figs. 9, 10). Provided this distinction is systematic, this realisation then allows an attempt to quantify the respective influences on Centre 3 magmas.

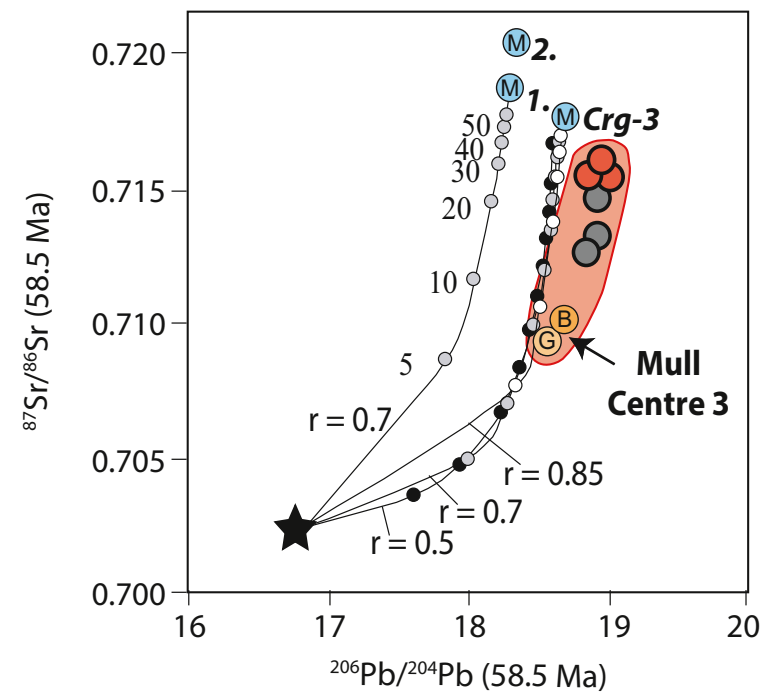

Loch Bà Felsite (Rhyolite) Loch Bà Inclusions

(G) Glen Cannel Microgranite

(B) Bein a' Ghraig Microgranite

(iM) Moine Metasediments (Mull)

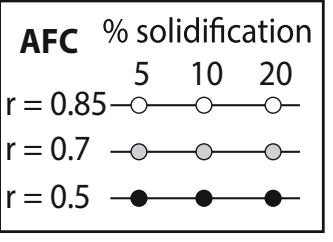

Fig. $12{ }^{206} \mathrm{~Pb} /{ }^{204} \mathrm{~Pb}$ vs. ${ }^{87} \mathrm{Sr} /{ }^{86} \mathrm{Sr}$ plot shows AFC models between MORB-type mantle-type parental magma and various Moine-type compositions (Mul-Moine-1 and Mul-Moine-CRG-3). The Sr vs. Pb models match best with a composition similar to sample Mul-MoineCRG-3. AFC calculation from Nicoll (2008) (see also Fig. 11)

\section{Magma-crust interaction at Mull}

Parental magmas of a depleted mantle-like isotope composition have previously been proposed for much of the BritishIrish Palaeocene Igneous Province (e.g. Gamble et al. 1992; Kerr et al. 1999; Ellam and Stuart 2000; Upton et al. 2002) and we envisage such an 'unradiogenic' parental magma composition for the Mull complex. Parental magmas of this type would be highly susceptible to contamination from radiogenic crustal rocks, especially if high concentration partial country rock melts are envisaged (Ellam and Stuart 2000; Troll et al. 2005). To provide a first order quantitative assessment, we use a MORB-type picrite composition from the Isle of Rum (Upton et al. 2002; Meyer et al. 2009) as a potential mantle-type end-member and couple this composition with Moine metasedimentary rocks from the Isle of Mull as crustal input (samples Mul-Moine-1, Mul-MoineCRG-3; Table 3). We then quantify the degree of interaction through assimilation and fractional crystallization-(AFC) calculations, as well as through two-component binary mixing calculations (cf. DePaolo 1981; Figs. 11, 12). Employing these end-member compositions, $\mathrm{Sr}$ and $\mathrm{Nd}$ isotopic ratios of the Loch Bà rhyolites can be reproduced by an AFC-type 
scenario that assimilates Moine metasedimentary rocks similar to sample Mul-Moine-1 $(r=0.7)$. Notably, such an AFC curve also intersects the isotopic ratios of the Loch Bà mafic inclusion (Figs. 11, 12). The modelled concentrations of $\mathrm{Sr}$ and Nd ppm (see Nicoll 2008) do, however, not accurately match the measured sample values of the Loch Bà rhyolite (measured $\mathrm{Sr}=74 \mathrm{ppm}, \mathrm{Nd}=54$; modelled $\mathrm{Sr}=280 \mathrm{ppm}$, $\mathrm{Nd}=30 \mathrm{ppm}$ ), and partial country rock melts (instead of whole-rock melts) are a possible reason for this mild mismatch, e.g. when considering micas and some feldspar contributed to the partial melt but some feldspar and also pyroxene was residual (cf. Duffield and Ruiz 1998; Troll et al. 2005).

In contrast, binary mixing trajectories between the MORB-type isotopic end-member and the Dalradian metasediments, or between MORB and the Ardnamurchan Moine metasedimentary rocks show that Centre 3 igneous samples do not follow these trajectories. The $\mathrm{Sr}-\mathrm{Nd}$ isotopic data of the Centre 3 samples can be reproduced, however, by mixing between a MORB-type magma and Moine metasedimentary rocks from Mull. This binary mixing model suggests between 10 and 30\% input of Mull Moine incorporation for the Glen Cannel and Beinn à Ghraig granites, whereas the Loch Bà rhyolite requires between 40 and $60 \%$ of this local Moine component. The mafic Loch Bà inclusions show lesser degrees of crustal involvement, ranging from $\sim 20$ to $\sim 30 \%$ for $\mathrm{Sr}$ and $\mathrm{Nd}$ isotopes. The uptake of local Moine metasedimentary crustal melts by Centre 3 magmas can be modelled as either binary mixing or indeed as high assimilation-rate AFC-style process (see Figs. 11, 12).

Moreover, our Pb isotope data, the first published for Centre 3 igneous rocks, are also consistent with Moine crustal additions (Figs. 10, 12). The Centre 3 data plot on a straight line that connects mantle-type compositions with the Moine compositional field (e.g. Ellam and Stuart 2000). Notably, the Glen Cannel and the Beinn a' Ghraig granites plot closer to mantle-proxies (cf. Ellam and Stuart 2000; Upton et al. 2002) relative to the Loch Bà suite and quantitative mixing models suggests $\sim 10 \%$ Moine-type crustal incorporation for the granitic samples (Figs. 11, 12). The Loch Bà rhyolites, in contrast, require $\geq 45 \%$ of local Moine metasedimentary incorporation, while the Loch Bà mafic inclusions record variable (20-50\%) Moine metasedimentary involvement. The mixing ratios derived for $\mathrm{Pb}$ isotopes data imply that most $\mathrm{Pb}$ in Centre 3 samples is crustal in origin and the mixing ratios derived from the $\mathrm{Sr}-\mathrm{Nd}$ isotope data presented above, are exceeded when using $\mathrm{Pb}$ isotope modelling. This observation confirms variable degrees of mixing between mantle-derived and local crustal components (Walker 1975; Kerr et al. 1999) and supports the notion of partial melting of crustal compositions (cf. Thompson et al. 1986; Kerr et al. 1995; Troll et al. 2005; Meade et al. 2009, 2014) to explain the Centre 3 isotope results.
Assimilation of basement gneiss, as sampled from Iona, or as exposed in the Lewisian complex elsewhere in NWScotland, is not evident in Centre 3 igneous rocks, including potentially deeper Lewisian "granulite-facies-type" material, as e.g. reported from the Isle of Skye (Dickin 1981; Thompson et al. 1986; Font et al. 2008). In fact, the Mull Centre 3 rocks do not record an influence of an unradiogenic ${ }^{206} \mathrm{~Pb} /{ }^{204} \mathrm{~Pb}$ component that is characteristic of Lewisian granulite-type compositions (Dickin 1981; Kerr et al. 1999) and thus contrast the earlier Mull Centre 1 intrusives, the older Mull Plateau lavas (Walsh et al. 1979; Morrison et al. 1985; Thompson et al. 1986), and also the Ardnamurchan cone sheets (Geldmacher et al. 1998, 2002). Whereas the presented data on Centre 3 support a lack of interaction of Centre 3 magmas with Lewisian-type basement, or a very minimal interaction only (see Fig. 9), Moine metasedimentary rocks are clearly documented as a major crustal influence. The Centre 3 igneous rocks thus share similarity with the earlier Mull acidic cone-sheets (EACS) described by Thomson (1986), or the Loch Scridain sill described by Preston et al. (1998), which seem to also have escaped significant interaction with Lewisian basement at depth, but record upper crustal magma contamination. This can be explained by either (1) rapid ascent of the Centre $3 \mathrm{mag}$ mas to shallow crustal levels, (2) shielding from contact with deep country rock due to earlier igneous intrusions at depth, or (3) via progressively inhibited crustal assimilation ("PICA" concept) where easily fusible components in the gneiss were previously extracted (cf. Gamble et al. 1992; Upton et al. 1998; Kerr et al. 1999; Meade et al. 2014), e.g. during Centre 1 and 2 activity (Fig. 13).

\section{Petrogenesis of Mull Centre 3}

On the basis of major element correlations in available mineral phases, Sparks (1988) proposed a closed-system fractional crystallization model for the evolution of the Loch Bà ring-dyke suite. This "extreme closed-system crystal fractionation" from a mafic parent was inspired by the closed-system fractionation model suggested for the Skærgaard intrusion in SE-Greenland (McBirney 1975; Hunter and Sparks 1987). However, the trace element and isotope data presented here do not support a closed-system scenario for the Mull Centre 3 compositions. Instead, magma-crust interaction is highlighted as a significant additional process in the petrogenetic history of the Centre 3 magmas and we propose a model whereby differentiation of ascending Centre 3 magmas was accomplished by assimilation of fusible parts of the local upper crust (cf. Walsh et al. 1979; Patchett 1980; Thompson et al. 1986; Preston et al. 1998; Kerr et al. 1999). Variable degrees of AFC-type processes involving Moine whole rocks and variable portions of partial melts, coupled with magma mixing, took place, consistent with 


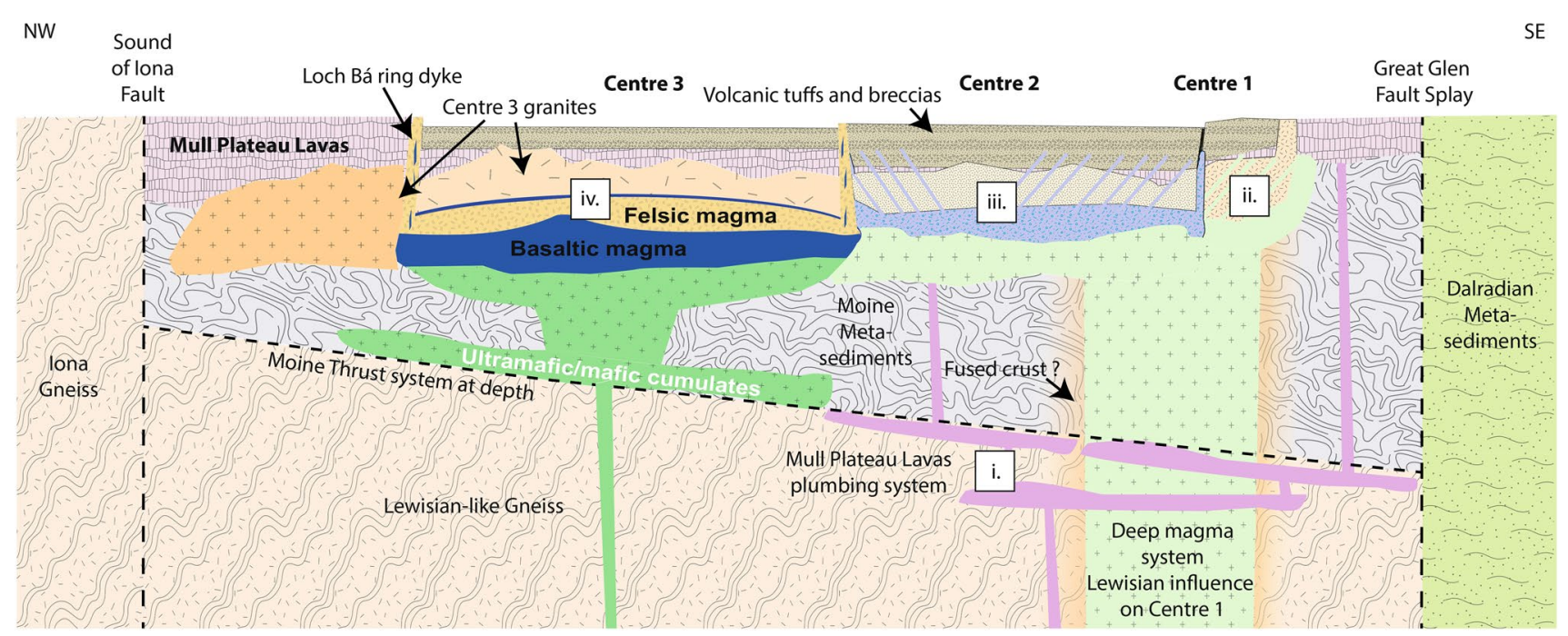

Fig. 13 Conceptual sketch of the evolution of the Palaeogene Mull volcanic Complex. The crustal structure is shown schematically and involves the Lewisian-like basement beneath the Moine metasedimentary suite of Mull. Also schematically represented are the gneisses and metasediments of Iona, located to the west of Mull which are uplifted relative to the gneissic basement beneath Mull, therefore representing a likely window into the deeper crustal structure. The Great Glen Fault marks the boundary to the Dalradian metasedimentary suite to the south, which seemed to have played no part in the igneous evolution of Centre 3. Magma ascent for Centre 3 was either via the shielded and or depleted plumbing region of Centre 1 followed by lateral transport to the NW, or via rapid ascent (through dykes) to high levels directly underneath Centre 3 . All samples of the Centre 3 magmatic suite record a dominantly Moine-type contamination signal derived from the local country rocks at shallow crustal levels. The main magma storage for Centre 3 was thus confined to the upper portions of the crust, probably ponding under the thermal and density barrier of the earlier Mull lavas the trace element and isotope evidence presented and with the relatively low-melting temperatures expected for Moine schist-type compositions that would allow considerable portions of Moine-derived crustal melts at relatively modest temperatures (cf. Patchett 1980; Thompson et al. 1986; Huppert and Sparks 1988; Meade et al. 2014). In this respect, we note that a simple AFC scenario does likely not apply as the Loch Bà rhyolites and the micro-granites show similar Sr contents and silica composition, yet show different $\mathrm{Sr}$-isotope ratios. Moine pelitic schist is the most distinct source of crustal input for Centre 3 magmas according to our isotope data, with the Loch Bà rhyolite showing the highest portion of crustal input. This contrasts most earlier felsic rocks from the Mull complex that usually also record initial Lewisian crustal inputs followed by upper crustal influences (Pankhurst et al. 1978; Walsh et al. 1979; Kerr et al. 1999). Prolonged deep storage seems thus to be recorded in the contamination pattern of many earlier Mull igneous rocks, whereas the main storage level recorded in the contamination signal for the Centre 3 magmas was much shallower, giving the impression of an overall upward migration of magma storage with time (cf. Walker 1975; Kerr et al. 1999; Troll et al. 2008b). This realisation is consistent with the observation that both Centre 3 microgranite bodies display drusy cavities and granophyric intergrowth (see Fig. 5), which is usually a sign of a shallow crustal emplacement of perhaps no more than $1.5-2 \mathrm{~km}$ below the former land surface (Emeleus 1961). These considerations would suggest an intrusion level right below the Mull plateau lavas and their underlying thin Mesozoic sediment cover $(\sim 200 \mathrm{~m})$ and into the substantial thickness of Moine metasedimentary rocks $(\sim 4-5 \mathrm{~km})$ below the thin Mesozoic sediments. Progressive supply of basic and intermediate magmas to this shallow crustal level could produce considerable quantities of crustal melt from the fertile Moine-type metasedimentary rocks (cf. Patchett 1980; Huppert and Sparks 1988; Meade et al. 2014), although such evolved crustal melts may not readily mix with mafic liquids (Blake et al. 1965; Walker and Skelhorn 1966; Kerr et al. 1999; Troll et al. 2004). We argue that this is the reason for the incompletely blended (stirred and mingled) Loch Bà rhyolite-andesite association. Finally, repeated injection of mafic magma into a shallow crustal rhyolitic reservoir represents a likely eruption trigger and may have caused violent pyroclastic eruptions and associated caldera collapse at Centre 3 (cf. Sparks et al. 1977; Sparks and Marshall 1986; Troll et al. 2004). While the two-component magmas may have been residing simultaneously in the shallow magma reservoir for some time (perhaps weeks to months), they were not side by side for too long, as otherwise isotopic equilibration would have been expected (cf. Troll and Schmincke 2002; Troll et al. 2004). 


\section{The role of Centre 3 within the evolution of the Mull complex}

Morrison et al. (1985) and Kerr et al. (1999) proposed that the style of crustal contamination at the Mull Complex changed over time (Fig. 13). Prior to activity at Centre 3, the Mull igneous complex had already been active for perhaps 2 Ma (cf. Chambers and Pringle 2001) and some of the magmas of the earlier Mull lavas seem to have stalled and fractionated at high pressure, e.g. at the base of the crust, where they assimilated Lewisian gneiss materials (Thompson et al. 1982; Morrison et al. 1985; Kerr et al. 1995, 1999). As the magmatic system beneath Mull matured, the focus of magma storage appears to have migrated upwards, and so the style of contamination changed because of the fusible Moine-type compositions that became available at shallow crustal levels. The presented REE and isotope data of Centre 3 rocks suggest a close affinity with the Moine psammites exposed in Eastern and Western Mull, which are present beneath Centre 3, and below what must have been a thick cover of Palaeocene basalt lava (> $1 \mathrm{~km}$; Bailey et al. 1924).

Indeed, Kerr et al. (1999) advocated that the Mull Igneous Complex has a very similar deep architecture to that seen at Skye (Bott and Tuson 1973) and Rum (Emeleus 1997; Emeleus and Troll 2014). Geophysical studies by Bott and Tantrigoda (1987) indicate that a large $+50 \mathrm{mGal}$ gravity anomaly exists beneath the Isle of Mull, which they interpreted as a thick $(6.5-13 \mathrm{~km})$ mafic or ultramafic pluton with a volume of between 2,000 and $3,600 \mathrm{~km}^{3}$. The granitic rocks on Mull appear to form a volumetrically very minor cap of maybe 1-2 km thickness only, beneath which the large mass of mafic to ultramafic rock commences. Following this line of thought, the granites of Centres 1,2 and 3 represent perhaps $10-20 \%$ of the total intrusion mass of the Mull complex (cf. Bott and Tantrigoda 1987; Kerr et al. 1999), confirming inferences from other well-studied centres in the region, such as Rum or Skye (Walker 1975; Emeleus 1997; Emeleus and Bell 2005). This realisation implies that acidic (felsic) rocks are a notable but ultimately volumetrically limited by-product of large-volume basaltic magmatism, even if they exceed pure fractionation derived volumes of felsic magma due to the mobilisation of felsic continental crust.

\section{Conclusion}

Mull Centre 3 is composed of several shallow-level microgranite and rhyolite intrusions that mark the closing stages of a major and prolonged period of Palaeocene igneous activity at Mull. Distinct compositional gaps in the major elemental data preserve a record of magma mixing, while REE patterns show the Centre 3 magmas also reflect melting and incorporation of Moine-type metasedimentary rocks from the local upper crust. Isotope data confirm magma-crust interaction for Centre 3 and the rhyolites of Loch Bà show the largest degree of crustal involvement with 50\% Moine-derived $\mathrm{Sr}$, $\mathrm{Nd}$ and $\mathrm{Pb}$. Likely, the Loch Bà rhyolite magma represents the culmination of heat input into the upper crust during Centre 3 activity. The Loch Bà mafic inclusions generally show lower crustal additions ( $\geq 20 \%)$, as do the surrounding Centre 3 granites (up to $15 \%$ ).

The successive Mull Igneous Centres (1-3), together with the extensive and successive lava units, appear to record an overall upward migration of their main magma storage zones that is recorded in their crustal assimilation patterns, with Centre 3 representing one of the final and shallowest episodes of activity. The interaction of Centre 3 magmas with shallow Moine-type metasedimentary crust only contrasts the earlier episodes of the Mull complex, where lower crustal Lewisian gneiss input is frequently detected. By the time Centre 3 was emplaced, magma pathways in the lower crust were likely well established and lined conduits may have shielded ascending magmas from interaction with gneissic materials. Alternatively, readily fusible material was perhaps already extracted from the lower crust during the earlier activity at the Mull complex and little fertile material may have been left at this point in the lower crust beneath the larger Mull igneous system.

Acknowledgements This article is dedicated to the memory of C. Henry Emeleus who passed away on November 11th, 2017. He will be missed dearly. We are grateful to Stephen Sparks, Morag Hendry, John Reavy, Fiona C. Meade, Colin H. Donaldson, Brian J. Upton, Graham McLeod, David Brown, Andrew C. Kerr and Eoghan P. Holohan for discussion and encouragement during the course of this study and we thank Anne Kelly and Vincent Gallagher (SUERC) and Dagmar Rau (GEOMAR) for analytical help in the laboratories. Journal reviews by Benjamin Ellis, Jörg Geldmacher and Andrew C. Kerr are much appreciated, as is the editorial handling by Gordon Moore. The project was supported by Science Foundation Ireland (SFI), the Royal Irish Academy (RIA) and by the Swedish Research Council (VR).

Funding Open Access funding provided by Uppsala University.

Open Access This article is licensed under a Creative Commons Attribution 4.0 International License, which permits use, sharing, adaptation, distribution and reproduction in any medium or format, as long as you give appropriate credit to the original author(s) and the source, provide a link to the Creative Commons licence, and indicate if changes were made. The images or other third party material in this article are included in the article's Creative Commons licence, unless indicated otherwise in a credit line to the material. If material is not included in the article's Creative Commons licence and your intended use is not permitted by statutory regulation or exceeds the permitted use, you will need to obtain permission directly from the copyright holder. To view a copy of this licence, visit http://creativecommons.org/licenses/by/4.0/. 


\section{References}

Abratis M, Schmincke H-U, Hansteen TH (2002) Composition and evolution of submarine rocks from the central and western Canary Islands. Int J Earth Sci 91:562-582

Bailey EB, Clough CT, Wright WB, et al (1924) The Tertiary and postTertiary geology of Mull, Loch Aline and Oban. Memoir of the geological survey of Great Britain, Sheet 44 (Scotland), HMSO, Edinburgh, UK.

Beckinsale RD, Pankhurst RJ, Skelhorn RR, Walsh JN (1978) Geochemistry and petrogenesis of the early Tertiary lava pile of the Isle of Mull, Scotland. Contrib to Mineral Petrol 66:415-427. https://doi.org/10.1007/BF00403427

Bell BR, Emeleus CH (1988) A review of silicic pyroclastic rocks of the British Tertiary Volcanic province. Geol Soc Lond Spec Publ 39:365-379. https://doi.org/10.1144/GSL.SP.1988.039.01.32

Blake DH, Elwell RWD, Gibson IL et al (1965) Some relationships resulting from the intimate association of acid and basic magmas. Q J Geol Soc 121:31-49. https://doi.org/10.1144/gsjgs.121.1.0031

Bott MHP, Tantrigoda DA (1987) Interpretation of the gravity and magnetic anomalies over the Mull Tertiary intrusive complex, NW Scotland. J Geol Soc Lond 144:17-28

Bott MHP, Tuson J (1973) Deep structure beneath the Tertiary Volcanic regions of Skye, Mull and Ardnamurchan, North-west Scotland. Nat Phys Sci 242:114-116. https://doi.org/10.1038/physc i2 $42114 \mathrm{a} 0$

Boynton WV (1984) Cosmochemistry of the rare earth elements: meteorite studies. In: Henderson P (ed) Rare earth element geochemistry. Elsevier, Amsterdam, pp 63-114

Chambers LM (2000) Age and duration of the British Tertiary igneous province. Implications for the development of the ancestral Iceland plume. $\mathrm{PhD}$ thesis. University of Edinburgh, Edinburgh

Chambers LM, Fitton JG (2000) Geochemical transitions in the ancestral Iceland plume: evidence from the Isle of Mull Tertiary volcano, Scotland. J Geol Soc London 157:261-263

Chambers LM, Pringle MS (2001) Age and duration of activity at the Isle of Mull Tertiary igneous centre, Scotland, and confirmation of the existence of subchrons during Anomaly 26r. Earth Planet Sci Lett 193:333-345. https://doi.org/10.1016/S0012 $-821 \mathrm{X}(01) 00499-\mathrm{X}$

Chambers LM, Pringle MS, Parrish RR (2005) Rapid formation of the Small Isles Tertiary centre constrained by precise ${ }^{40} \mathrm{Ar} /{ }^{39} \mathrm{Ar}$ and U-Pb ages. Lithos 79:367-384. https://doi.org/10.1016/j. lithos.2004.09.008

DePaolo DJ (1981) Trace element and isotopic effects of combined wallrock assimilation and fractional crystallization. Earth Planet Sci Lett 53:189-202. https://doi.org/10.1016/0012821X(81)90153-9

Dickin AP (1981) Isotope geochemistry of Tertiary igneous rocks from the Isle of Skye, NW. Scotland J Petrol 22:155-189. https ://doi.org/10.1093/petrology/22.2.155

Dickin AP, Brown JL, Thompson RN et al (1984) Crustal contamination and the granite problem in the British Tertiary Volcanic Province [and discussion]. Philos Trans R Soc A Math Phys Eng Sci 310:755-780. https://doi.org/10.1098/rsta.1984.0018

Duffield WA, Ruiz J (1998) A model that helps explain Sr-isotope disequilibrium between feldspar phenocrysts and melt in largevolume silicic magma systems. J Volcanol Geotherm Res 87:713. https://doi.org/10.1016/S0377-0273(98)00071-7

Ellam RM (2006) New constraints on the petrogenesis of the Nuanetsi picrite basalts from $\mathrm{Pb}$ and $\mathrm{Hf}$ isotope data. Earth Planet Sci Lett 245:153-161. https://doi.org/10.1016/j. eps1.2006.03.004

Ellam RM, Stuart FM (2000) The sub-lithospheric source of North Atlantic basalts: evidence for, and significance of a common end-member. J Petrol 41:919-932. https://doi.org/10.1093/petro $\log / 41.7 .919$

Emeleus CH (1961) The porphyritic felsite of the Tertiary ring complex of Slieve Gullion, Co. Armagh Proc R Ir Acad B 62:55-76

Emeleus CH (1997) Geology of Rum and the adjacent islands. The Stationary Office, London

Emeleus CH, Bell BR (2005) British regional geology: the Palaeogene Volcanic districts of Scotland, 4th edn. British Geological Survey, Nottingham

Emeleus CH, Troll VR (2014) The Rum Igneous Centre, Scotland. Mineral Mag 78:805-839. https://doi.org/10.1180/minma g.2014.078.4.04

Fitton JG, Saunders AD, Larsen LM, et al (1998) Volcanic rocks from the southeast Greenland Margin at $63^{\circ} \mathrm{N}$ : composition, petrogenesis, and mantle sources. In: Proceedings of the ocean drilling program, 152 scientific results. ocean drilling program, pp 331-350

Font L, Davidson JP, Pearson DG et al (2008) Sr and Pb isotope microanalysis of plagioclase crystals from Skye Lavas: an insight into open-system processes in a flood basalt province. J Petrol 49:1449-1471. https://doi.org/10.1093/petrology/egn032

Friend C, Kinny P (2001) A reappraisal of the Lewisian Gneiss Complex: geochronological evidence for its tectonic assembly from disparate terranes in the Proterozoic. Contrib Mineral Petrol 142:198-218. https://doi.org/10.1007/s004100100283

Fyfe J, Long D, Evans D (1993) The geology of the Malin-Hebrides sea area. British Geological Survey, United Kingdom Offshore Regional Report

Gamble JA (1979) Some relationships between coexisting granitic and basaltic magmas and the genesis of hybrid rocks in the tertiary central complex of Slieve Gullion, northeast Ireland. J Volcanol Geotherm Res 5:297-316. https://doi.org/10.1016/03770273(79)90021-0

Gamble JA, Meighan IG, McCormick AG (1992) The petrogenesis of Tertiary microgranites and granophyres from the Slieve Gullion Central Complex, NE Ireland. J Geol Soc London 149:93-106. https://doi.org/10.1144/gsjgs.149.1.0093

Geldmacher J, Haase KM, Devey CW, Garbe-Schönberg CD (1998) The petrogenesis of Tertiary cone-sheets in Ardnamurchan, NW Scotland: petrological and geochemical constraints on crustal contamination and partial melting. Contrib Mineral Petrol 131:196209. https://doi.org/10.1007/s004100050388

Geldmacher J, Troll VR, Emeleus CH, Donaldson CH (2002) Pb-isotope evidence for contrasting crustal contamination of primitive to evolved magmas from Ardnamurchan and Rum: implications for the structure of the underlying crust. Scott J Geol 38:55-61. https://doi.org/10.1144/sjg38010055

Holdsworth RE, Strachan RA, Harris AL (1994) Precambrian rocks in northern Scotland east of the Moine Thrust. In: Gibbons W, Harris AL (eds) A revised correlation of Pre-Cambrian rocks in the British Isles. Geological Society of London Special Report No. 22, pp 23-32

Hunter RH, Sparks RSJ (1987) The differentiation of the Skaergaard intrusion. Contrib Mineral Petrol 95:451-461. https://doi. org/10.1007/BF00402205

Huppert HE, Sparks RSJ (1988) The generation of granitic magmas by intrusion of Basalt into continental crust. J Petrol 29:599-624. https://doi.org/10.1093/petrology/29.3.599

Kerr AC (1993) Elemental evidence for an enriched small-fraction-melt input into Tertiary Mull basalts, Western Scotland. J Geol Soc London 150:763-769. https://doi.org/10.1144/gsjgs.150.4.0763

Kerr AC (1995a) The geochemistry of the Mull-Morvern Tertiary lava succession, NW Scotland: an assessment of mantle sources during plume-related volcanism. Chem Geol 122:43-58. https://doi. org/10.1016/0009-2541(95)00009-B

Kerr AC (1995b) The geochemical stratigraphy, field relations and temporal variation of the Mull-Morvern Tertiary lava succession, 
NW Scotland. Trans R Soc Edinb Earth Sci 86:35-47. https://doi. org/10.1017/S0263593300002145

Kerr AC, Kempton PD, Thompson RN (1995) Crustal assimilation during turbulent magma ascent (ATA); new isotopic evidence from the Mull Tertiary lava succession, N W Scotland. Contrib Mineral Petrol 119:142-154. https://doi.org/10.1007/BF00307277

Kerr AC, Kent RW, Thomson BA et al (1999) Geochemical evolution of the Tertiary Mull volcano, western Scotland. J Petrol 40:873908. https://doi.org/10.1093/petroj/40.6.873

Kinny PD, Friend CRL, Love GJ (2005) Proposal for a terrane-based nomenclature for the Lewisian Gneiss complex of NW Scotland. J Geol Soc London 162:175-186. https://doi.org/10.1144/0016764903-149

Lewis JD (1968) Form and structure of the Loch Ba ring dyke, Isle of Mull. Proc Geol Soc London 1649:110-111

Marshall LA (1984) Origin of mixed magma and net-veined ring intrusions. PhD thesis, University of Cambridge

McAteer CA, Daly JS, Flowerdew MJ et al (2014) Sedimentary provenance, age and possible correlation of the Iona Group SW Scotland. Scott J Geol 50:143-158. https://doi.org/10.1144/sjg2013-019

McBirney AR (1975) Differentiation of the Skaergaard intrusion. Nature 253:691-694. https://doi.org/10.1038/253691a0

Meade FC, Chew DM, Troll VR et al (2009) Magma ascent along a major Terrane Boundary: Crustal contamination and magma mixing at the Drumadoon intrusive complex, Isle of Arran, Scotland. J Petrol 50:2345-2374. https://doi.org/10.1093/petrology/egp081

Meade FC, Troll VR, Ellam RM et al (2014) Bimodal magmatism produced by progressively inhibited crustal assimilation. Nat Commun 5:1-11. https://doi.org/10.1038/ncomms5199

Meyer R, Nicoll GR, Hertogen JGH et al (2009) Trace element and isotope constraints on crustal anatexis by upwelling mantle melts in the North Atlantic Igneous Province: an example from the Isle of Rum. NW Scotland Geol Mag 146:382. https://doi.org/10.1017/ S0016756809006244

Morrison MA, Thompson RN, Dickin AP (1985) Geochemical evidence for complex magmatic plumbing during development of a continental volcanic center. Geology 13:581. https://doi. org/10.1130/0091-7613(1985)13\%3c581:GEFCMP\%3e2.0.CO;2

Nicoll GR (2008) Evolution and crustal contamination of igneous rocks from the Palaeocene Volcanic District of North-West Scotland. Unpublished Ph.D. thesis, Trinity College, Dublin. http://hdl. handle.net/2262/78127

Nicoll GR, Holness MB, Troll VR et al (2009) Early mafic magmatism and crustal anatexis on the Isle of Rum: evidence from the Am Màm intrusion breccia. Geol Mag 146:368. https://doi. org/10.1017/S0016756808005864

Pankhurst RJ, Walsh JN, Beckinsale RD, Skelhorn RR (1978) Isotopic and other geochemical evidence for the origin of the Loch Uisg Granophyre, Isle of Mull, Scotland. Earth Planet Sci Lett 38:355363. https://doi.org/10.1016/0012-821X(78)90109-7

Park RG (2005) The Lewisian terrane model: a review. Scott J Geol 41:105-118. https://doi.org/10.1144/sjg41020105

Patchett PJ (1980) Thermal effects of basalt on continental crust and crustal contamination of magmas. Nature 283:559-561. https:// doi.org/10.1038/283559a0

Potts GJ, Hunter RH, Harris AL, Fraser FM (1995) Late-orogenic extensional tectonics at the NW margin of the Caledonides in Scotland. J Geol Soc Lond 152:907-910. https://doi.org/10.1144/ GSL.JGS.1995.152.01.04

Preston RJ, Bell BR, Rogers G (1998) The Loch Scridain xenolithic sill complex, Isle of Mull, Scotland: fractional crystallization, assimilation, magma-mixing and crustal anatexis in Subvolcanic Conduits. J Petrol 39:519-550. https://doi.org/10.1093/petroj/39.3.519

Richey JE (1932) The tertiary ring complex of Slieve Gullion (Ireland), with petrological notes by Herbert Henry Thomas. Q J Geol Soc 88:776-849. https://doi.org/10.1144/GSL.JGS.1932.088.01-04.25
Smythe DK (1987) Deep seismic reflection profiling of the Lewisian foreland. Geol Soc Lond Spec Publ 27:193-203. https://doi. org/10.1144/GSL.SP.1987.027.01.17

Sparks RSJ (1988) Petrology and geochemistry of the Loch Ba ringdyke, Mull (NW Scotland): an example of the extreme differentiation of tholeiitic magmas. Contrib Mineral Petrol 100:446-461. https://doi.org/10.1007/BF00371374

Sparks RSJ, Marshall LA (1986) Thermal and mechanical constraints on mixing between mafic and silicic magmas. J Volcanol Geotherm Res 29:99-124. https://doi.org/10.1016/03770273(86)90041-7

Sparks SRJ, Sigurdsson H, Wilson L (1977) Magma mixing: a mechanism for triggering acid explosive eruptions. Nature 267:315-318. https://doi.org/10.1038/267315a0

Strachan RA, Smith M, Harris AL, Fettes DJ (2002) The northern highlands and grampian terranes. In: Trewin NH (ed) The geology of Scotland, 4th edn. The Geological Society, London, pp 81-147

Thompson RN, Dickin AP, Gibson IL, Morrison MA (1982) Elemental fingerprints of isotopic contamination of hebridean Palaeocene mantle-derived magmas by archaean sial. Contrib Mineral Petrol 79:159-168. https://doi.org/10.1007/BF01132885

Thompson RN, Morrison MA, Dickin AP et al (1986) Two contrasting styles of interaction between basic magmas and continental crust in the British Tertiary Volcanic Province. J Geophys Res 91:5985. https://doi.org/10.1029/JB091iB06p05985

Thomson BA (1986) The petrology and geochemistry of the Tertiary cone-sheet complex, Island of Mull, Scotland. Unpublished Ph.D. Thesis, University of London

Troll VR, Chadwick JP, Ellam RM et al (2005) Sr and Nd isotope evidence for successive crustal contamination of Slieve Gullion ringdyke magmas, Co. Armagh, Ireland. Geol Mag 142:659. https:// doi.org/10.1017/S0016756805001068

Troll VR, Donaldson CH, Emeleus CH (2004) Pre-eruptive magma mixing in ash-flow deposits of the Tertiary Rum Igneous Centre, Scotland. Contrib Mineral Petrol 147:722-739. https://doi. org/10.1007/s00410-004-0584-0

Troll VR, Meade FC, Chew DM, Emeleus CH (2008a) A new exposure of a caldera fault segment at the Slieve Gullion Igneous centre: implications for the emplacement of the early ring-complex. Irish J Earth Sci 26:1-16

Troll VR, Nicoll GR, Donaldson CH, Emeleus CH (2008b) Dating the onset of volcanism at the Rum Igneous Centre, NW Scotland. J Geol Soc Lond 165:651-659. https://doi.org/10.1144/0016-76492 006-190

Troll VR, Emeleus H, Nicoll GR, Mattsson T, Ellam R, Donaldson $\mathrm{CH}$, Harris C (2019) A large explosive silicic eruption in the British Palaeogene Igneous Province. Sci Rep 9:494. https://doi. org/10.1038/s41598-018-35855-w

Troll VR, Schmincke HU (2002) Magma mixing and crustal recycling recorded in ternary feldspar from compositionally zoned peralkaline Ignimbrite A', Gran Canaria, Canary Islands. J Petrol 43:243-270. https://doi.org/10.1093/petrology/43.2.243

Upton BGJ, Aspen P, Rex DC et al (1998) Lower crustal and possible shallow mantle samples from beneath the Hebrides: evidence from a xenolithic dyke at Gribun, western Mull. J Geol Soc Lond 155:813-828. https://doi.org/10.1144/gsigs.155.5.0813

Upton BGJ, Skovgaard AC, McClurg JE et al (2002) Picritic magmas and the Rum ultramafic complex Scotland. Geol Mag. https://doi. org/10.1017/S0016756802006684

Vogel TA, Younker LW, Wilband JT, Kampmueller E (1984) Magma mixing: the Marsco suite, Isle of Skye, Scotland. Contrib Mineral Petrol 87:231-241. https://doi.org/10.1007/BF00373056

Walker GPL (1975) A new concept of the evolution of the British Tertiary intrusive centres. J Geol Soc London 131:121-141. https:// doi.org/10.1144/gsjgs.131.2.0121 
Walker GPL, Skelhorn RR (1966) Some associations of acid and basic igneous rocks. Earth Science Rev 2:93-109. https://doi. org/10.1016/0012-8252(66)90024-9

Walsh JN, Beckinsale RD, Skelhorn RR, Thorpe RS (1979) Geochemistry and petrogenesis of Tertiary granitic rocks from the Isle of Mull Northwest Scotland. Contrib Mineral Petrol 71:99-116
Publisher's Note Springer Nature remains neutral with regard to jurisdictional claims in published maps and institutional affiliations. 